\title{
A Survey on the Application of WirelessHART for Industrial Process Monitoring and Control
}

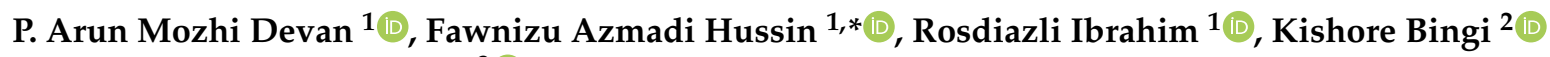 \\ and Farooq Ahmad Khanday ${ }^{3}$ (D) \\ 1 Department of Electrical and Electronics Engineering, Universiti Teknologi PETRONAS, \\ Seri Iskandar 32610, Malaysia; arun_18003272@utp.edu.my (P.A.M.D.); rosdiazli@utp.edu.my (R.I.) \\ 2 School of Electrical Engineering, Vellore Institute of Technology, Vellore 632014, India; kishore.bingi@vit.ac.in \\ 3 Department of Electronics and Instrumentation Technology, University of Kashmir, Srinagar 190006, India; \\ farooqkhanday@kashmiruniversity.ac.in \\ * Correspondence: fawnizu@utp.edu.my
}

check for

updates

Citation: Devan, P.A.M.

Hussin, F.A.; Ibrahim, R.; Bingi, K.;

Khanday, F.A. A Survey on the

Application of WirelessHART for

Industrial Process Monitoring and

Control. Sensors 2021, 21, 4951.

https://doi.org/10.3390/s21154951

Received: 08 May 2021

Accepted: 08 June 2021

Published: 21 July 2021

Publisher's Note: MDPI stays neutral with regard to jurisdictional claims in published maps and institutional affiliations.

Copyright: (c) 2021 by the authors. Licensee MDPI, Basel, Switzerland. This article is an open access article distributed under the terms and conditions of the Creative Commons Attribution (CC BY) license (https:// creativecommons.org/licenses/by/ $4.0 /)$.

\begin{abstract}
Industrialization has led to a huge demand for a network control system to monitor and control multi-loop processes with high effectiveness. Due to these advancements, new industrial wireless sensor network (IWSN) standards such as ZigBee, WirelessHART, ISA 100.11a wireless, and Wireless network for Industrial Automation-Process Automation (WIA-PA) have begun to emerge based on their wired conventional structure with additional developments. This advancement improved flexibility, scalability, needed fewer cables, reduced the network installation and commissioning time, increased productivity, and reduced maintenance costs compared to wired networks. On the other hand, using IWSNs for process control comes with the critical challenge of handling stochastic network delays, packet drop, and external noises which are capable of degrading the controller performance. Thus, this paper presents a detailed study focusing only on the adoption of WirelessHART in simulations and real-time applications for industrial process monitoring and control with its crucial challenges and design requirements.
\end{abstract}

Keywords: automation; control system; fractional-order control; industrial wireless sensor networks; network control system; process control; WirelessHART; wireless control

\section{Introduction}

The network control system has been widely adopted in process industries and manufacturing plants producing goods such as food and beverages, chemicals, pulp and paper, crude oil refineries, and power generation plants to control and monitor field instruments. These industrial control systems consist of a single instrument or a group of instruments that form a single- or multiple-loop network based on their design and deployment. To maintain a steady output response in a system, the industrial control system must continuously monitor and maintain the parameters at desired levels. Hence, industries need to control and monitor numerous field devices that humans often handle. In the initial industrial era, communication between field devices and control systems took place via 4-20 mA analog signals, causing more errors that resulted in process instability and additional external noise [1,2]. Thus, the concept of applying automated networking control systems to industrial processes has grown in many applications, yielding autonomous controllers without the need for any human intervention. This has led to the hybridization of combining analog and digital signals to create new wired communication protocols. These include, to list a few, FOUNDATION ${ }^{\mathrm{TM}}$ Fieldbus, Modbus, PROFIBUS, ISA 100.11a, and highway addressable remote transducer (HART), as well as their upgraded wireless versions, such as ZigBee, WirelessHART, ISA 100.11a wireless, and WIA-PA [3,4]. For an industrial wireless sensor network (IWSNs) to be used in industry, it must provide the 
same quality of controlling and monitoring service as-or better than-conventional wired communication systems $[5,6]$. Some of the advantages of IWSNs over wired networks are:

- $\quad$ They can eliminate the costly and bulky cabling used to connect the various field devices [7];

- They will dramatically reduce the deployment, redeployment, installation, and commissioning times, thus avoiding the problem of frequent cable maintenance [8];

- $\quad$ They will be self-organized and support a large number of battery-powered wireless nodes [9];

- $\quad$ They can be installed at any location irrespective of the surrounding environmental conditions [10].

The advancement in communication technologies changed control strategies from being based on electronic single control loops in the 1960s to single digital loop controllers in the 1970s. Multi-loop digital controllers were designed for single process plants in the 1980s. The present wireless digital controller is shown in Figure 1 [11]. Self-diagnostic functionalities in wireless field instruments have encouraged process industries to shift from wired to wireless technologies, supporting both analog and digital instrument installation in any environment. Figure 2 shows a classical IWSN architecture, where multiple wireless nodes are placed in plants remotely and controlled through wireless networks. The closed-loop control system consists of both continuous-time and discrete-time data of the sensors, actuators, and controllers integrated with the process plant. In the closed-loop system, both the host application and the gateway will run on the same system to avoid the possible delay and clock drift. This closed-loop structure is the same in all existing wireless networks.

$\begin{array}{cccc}\text { 1960s } & 1970 \mathrm{~s} & 1980 \mathrm{~s} & 2000 \mathrm{~s} \\ \begin{array}{c}\text { Single-Loop } \\ \text { Electronic } \\ \text { Controller }\end{array} & \begin{array}{c}\text { Single-Loop } \\ \text { Digital } \\ \text { Controller }\end{array} & \begin{array}{c}\text { Multi-Loop } \\ \text { Digital } \\ \text { Controller }\end{array} & \begin{array}{c}\text { Wireless } \\ \text { Digital } \\ \text { Controller }\end{array}\end{array}$

Figure 1. Evolution of wireless digital controllers.

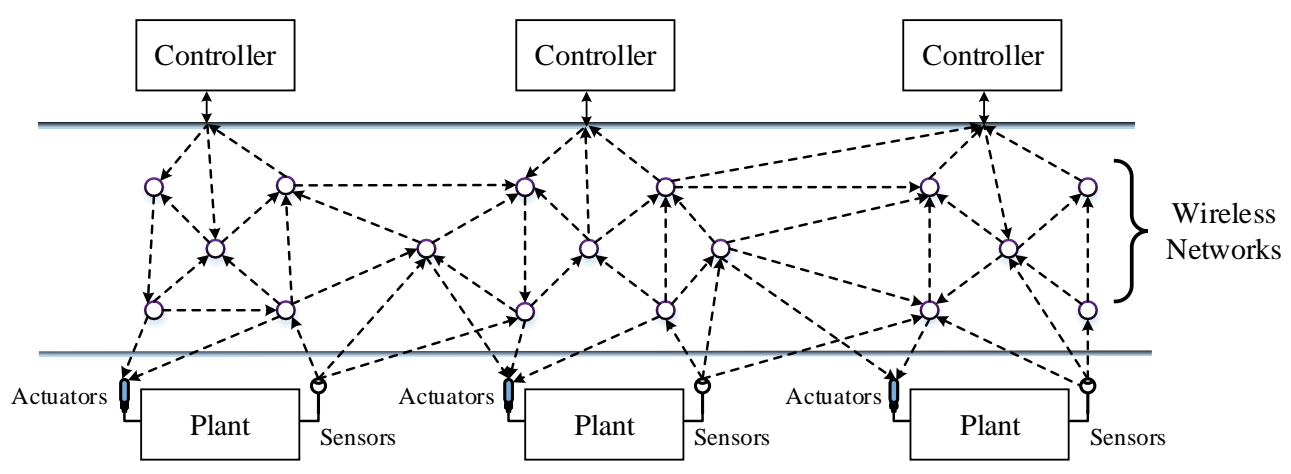

Figure 2. IWSN architecture.

The overall classification of the IWSN communication protocols is shown in Figure 3. From the figure, it can be seen that all the IWSN standards are based on the physical layer IEEE802.14.5 standard. However, modifications were carried out in the physical layer to suit the specific application needs of each standard. A significant characteristic of the WirelessHART is its time-synchronized MAC layer specification [4]. Additionally, its MAC header is designed in such a way that it supports the co-existence of other IWSN protocols, such as Wi-Fi, ZigBee, ISA 100.11a, and WIA-PA. Table 1 shows a summary of a survey conducted by ISA, HART Communication Foundation, and Wireless Industrial Networking Alliance in collaboration with "ON World" to understand the factors influencing the 
adoption of IWSN among vendors and end-users [12,13]. The foremost concern in the adoption of industrial applications is data accuracy and data protection against malware attacks and hacking. The next concern relates to easy data access for field devices and the adaptability of universal industrial standards. In addition, industries are unwilling to take the risk to deploy large-scale sensor nodes unless widely accepted industrial standards back them. Due to these reasons, industries are seeking inter-operable standards to deploy wireless field devices. Additionally, the crucial research improvements in IWSNs increased the market cap value from $\$ 944.92$ million to $\$ 3.795$ billion [3]. In addition, this trend is continuing to grow even faster in the forthcoming years due to the rapid industrial developments (Fourth Industrial Revolution (IR 4.0)). To deal with the anticipated trends, more research development solutions focusing on signal reliability, inter-operability, compactness, effective data transmission, and fault tolerance characteristics are essentially needed for the IWSN protocols.

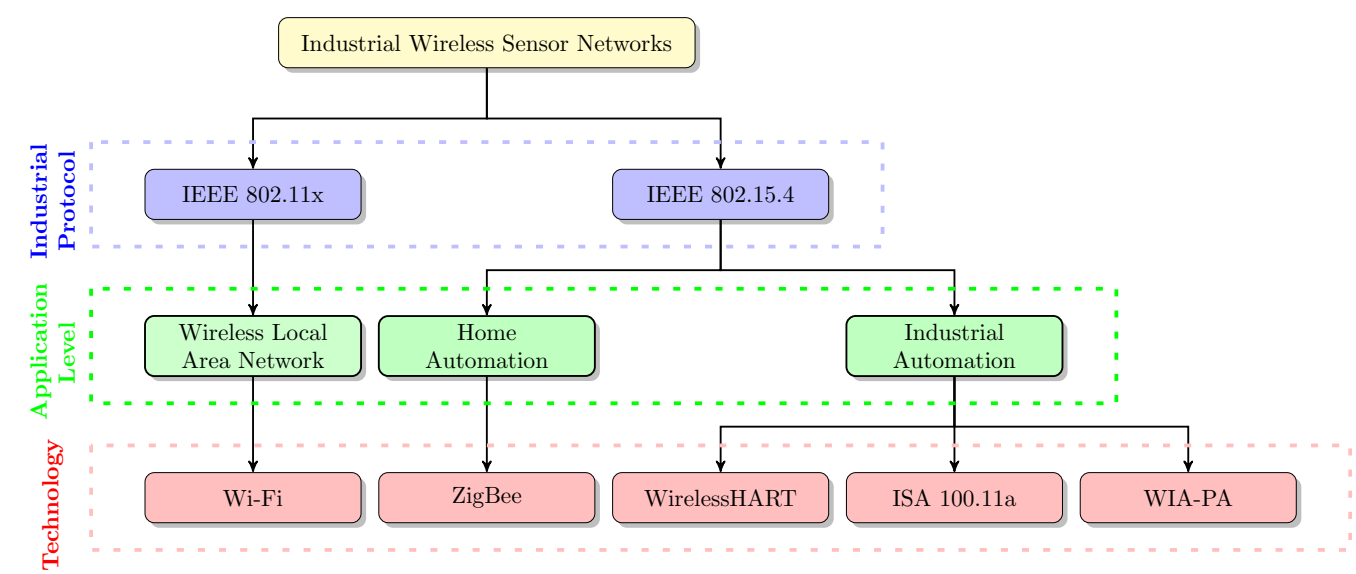

Figure 3. Classification of industrial wireless sensor networks.

Table 1. Adopting factors for wireless technology in industrial automation [13].

\begin{tabular}{lcc}
\hline \multicolumn{1}{c}{ Factors } & $\mathbf{2 0 1 2} \mathbf{( \% )}$ & $\mathbf{2 0 1 4}(\mathbf{\% )})$ \\
\hline Data Accuracy & 96 & 96 \\
Data Protection & 89 & 87 \\
Data Accessibility & 71 & 69 \\
Industrial Standards & 68 & 62 \\
Cost Effective & 61 & 59 \\
IP Compatibility & 45 & 54 \\
Battery Lifetime & 68 & 51 \\
\hline
\end{tabular}

Table 2 summarizes the comparison between features of the most commonly used industrial wireless standards. In the table, it can be seen that the three industrial standards WIA-PA, ISA100.11a, and WirelessHART share several features in common. These features include security, reliability, scalability, topology, and low power consumption. The main objective of the paper is to survey the implementation of WirelessHART in industrial process control in both simulations and real-time environments. Figure 4 gives the hierarchical flow of the paper organization. The figure gives brief information about every section present in the article. Additionally, other important contributions to the field of process control from this research paper will be given as follows:

1. Evolution of the IWSN with its architecture and classification;

2. Progression of the industrial process automation using IWSN;

3. How the WirelessHART protocol dominates the process control industries;

4. WirelessHART network architecture with its OSI layer structure; 
5. Detailed survey of the utilization of WirelessHART for industrial process control in simulation and real-time implementation;

6. Design challenges and application-based requirements for the WirelessHART network;

7. Possible research and development solutions for the WirelessHART network requirements and challenges.

Table 2. Features comparison between the different industrial wireless sensor networks [14].

\begin{tabular}{ccccc}
\hline \multirow{2}{*}{ Features } & \multicolumn{4}{c}{ Standard } \\
\cline { 2 - 5 } & ZigBee & WirelessHART & ISA100.11a & WIA-PA \\
\hline Data Security & High & Very High & Very High & Very High \\
\hline Scalability & Medium & High & High & High \\
\hline Power Usage & Low & Low & Low & Low \\
\hline $\begin{array}{c}\text { Data Transfer } \\
\text { Rate }\end{array}$ & Low (20-250 kbps $)$ & \\
\hline $\begin{array}{c}\text { Network } \\
\text { Topology }\end{array}$ & Star/Mesh/Tree & Star/Mesh & Star/Mesh & Hybrid \\
\hline $\begin{array}{c}\text { Data } \\
\text { Reliability }\end{array}$ & Low & Very High & Very High & Very High \\
\hline $\begin{array}{c}\text { Routing } \\
\text { Capability }\end{array}$ & Limited & Full & Full/Limited & Limited \\
\hline $\begin{array}{c}\text { Channel } \\
\text { Hopping }\end{array}$ & No & Yes & Yes & Yes \\
\hline $\begin{array}{c}\text { Frequency } \\
\text { channels }\end{array}$ & 27 (All Bands) & 15 (2.4 GHz) & 16 (2.4 GHz) & 16 (2.4 GHz) \\
\hline $\begin{array}{c}\text { Manager } \\
\text { Architecture }\end{array}$ & $\begin{array}{c}\text { Centralized/ } \\
\text { Distributed }\end{array}$ & Centralized & Centralized & $\begin{array}{c}\text { Centralized/ } \\
\text { Distributed }\end{array}$ \\
\hline
\end{tabular}

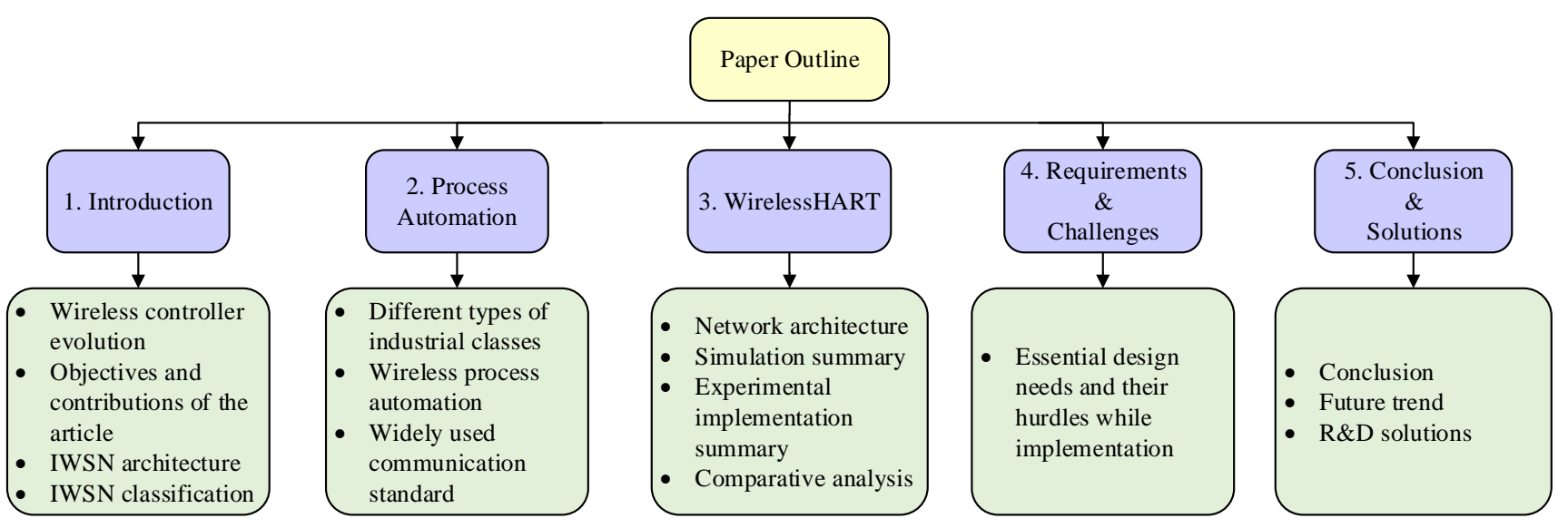

Figure 4. Content organization of the paper.

Furthermore, the scope of the survey presented in this paper is different from that of other review articles. Numerous interrelated research articles were utilized to provide an extensive literature analysis of the WirelessHART implementation in industrial process control. Here, all of them are organized based on several factors, such as network analysis, type of field device used, network topology, simulator tool used, and the controller used in both the simulation and real-time environments with its challenges and design require- 
ments. Comprehensive studies of the existing IWSN communication protocol's network architecture, design, and standardization can be found in [3,6,15-17].

This paper's remaining sections are organized as follows: Section 2 provides an introduction relating the importance of wireless networks in process control automation with the classification of different industrial processes with their functions. Section 3 gives a detailed analysis of WirelessHART in process monitoring and control applications in simulations and real-time environments, along with its industrial network architecture. Section 4 describes the challenges and design requirements for WirelessHART with various limitations and its possible research solutions, followed by a summary and conclusion in Section 5 .

\section{Background of Process Automation}

For many decades, industrial process plants have used analog signals in the wired channel for communication with field devices (sensors) to take appropriate control actions to ensure process stability $[15,18]$. The most commonly used communication protocols, such as HART, Fieldbus, Modbus, and PROFIBUS, emerged in the mid-1980s. However, wireless technological advancements required the development of industry-standard wireless protocols for them to be used in process monitoring and control. These wireless communication protocols require small- to mid-scale network infrastructures consisting of multiple sensor nodes working together to acquire data from field devices installed in different environments. Their design is based on the application-specific requirements, since each industrial process has multiple objectives and different infrastructure needs [3] In the past few years, IWSNs have emerged in numerous application fields, including personal health monitoring [19], building and civil infrastructure monitoring [20,21], automotive applications [22], power converters [23], power and smart grids [24], energy harvesting [25], smart cities [26], agriculture [27], food processing [28], underwater wireless sensor networks [29,30], and environment monitoring [31].

Process and industrial automation fields, such as steel manufacturing, oil and gas, pulp and paper, and power generation, have started to gradually adopt IWSNs because of the new technological advancements made and the possible flexibility in handling complex closed-loop processes [32]. In industrial processes, they were expected to achieve about $80 \%$ of the market share in 2020 by overtaking wired networks at the field level due to their efficient and easily deployable infrastructure [33]. The main reason for adopting wireless motes is due to their operational and installation cost reduction of up to $60 \%$ in comparison with conventional wired field devices, according to an industry operation survey overseen by Emerson Process Management [34,35].

\subsection{Process Control Automation}

The applications of process control can be classified into three distinct sub-categories based on the control system point of view, as presented in Table 3 [36]. A brief classification for each is given underneath.

\subsubsection{Safety and Supervisory Control}

The transmission of sensor data to the controller in safety and supervisory control is very much essential. Additionally, issues such as packet loss and latency cannot be tolerated because these are emergency control systems, and their failure will lead to catastrophic accidents. Thus, sensors connected to these systems are always in standby mode, with a maximum permitted latency of $10 \mathrm{~ms}$.

\subsubsection{Closed-Loop Control}

Closed-loop control is a conventional system that has a controller maintaining the desired set-point of the process. Here, dead-time and external noise cause significant issues, while the maximum allowed latency varies from 10 to $100 \mathrm{~ms}$, with a less critical rate in comparison with emergency class systems. 


\subsubsection{Monitoring and Control}

In this classification of control systems, latency is not considered an essential factor in taking control actions and there is a maximum allowed latency of $1000 \mathrm{~ms}$. Here, field device data are commonly utilized to perform maintenance operations for calibration and repair. However, in some cases, data transfer consistency is needed to continue the process operations.

Table 3. Classes of industrial process automation.

\begin{tabular}{llllll}
\hline \multicolumn{1}{c}{ Category } & Latency & \multicolumn{1}{c}{ Class } & Description & \multicolumn{1}{c}{ End Function } & Field Devices \\
\hline $\begin{array}{l}\text { Safety and } \\
\text { Supervisory }\end{array}$ & \multirow{2}{*}{$10 \mathrm{~ms}$} & $\begin{array}{l}\text { Emergency } \\
\text { control }\end{array}$ & $\begin{array}{l}\text { Always } \\
\text { critical }\end{array}$ & $\begin{array}{l}\text { Emergency } \\
\text { shutdown }\end{array}$ & $\begin{array}{l}\text { Vibration sensor } \\
\text { Gas sensor } \\
\text { Sprinklers }\end{array}$ \\
\hline \multirow{2}{*}{$\begin{array}{l}\text { Closed-loop } \\
\text { Control }\end{array}$} & \multirow{2}{*}{$10-100 \mathrm{~ms}$} & $\begin{array}{l}\text { Regulatory } \\
\text { control }\end{array}$ & $\begin{array}{l}\text { Often } \\
\text { critical }\end{array}$ & $\begin{array}{l}\text { Field device } \\
\text { control }\end{array}$ & $\begin{array}{l}\text { Control valve } \\
\text { Flow meter }\end{array}$ \\
\cline { 3 - 5 } & & $\begin{array}{l}\text { Supervisory } \\
\text { control }\end{array}$ & $\begin{array}{l}\text { Mostly } \\
\text { non-critical }\end{array}$ & $\begin{array}{l}\text { Control loops } \\
\text { optimization }\end{array}$ & \\
\hline \multirow{4}{*}{$\begin{array}{l}\text { Monitoring } \\
\text { and } \\
\text { Control }\end{array}$} & \multirow{2}{*}{$100-1000 \mathrm{~ms}$} & $\begin{array}{l}\text { Open-loop } \\
\text { control }\end{array}$ & $\begin{array}{l}\text { Corrective } \\
\text { maintenance }\end{array}$ & $\begin{array}{l}\text { Manual process } \\
\text { shutdown }\end{array}$ & Proximity sensor \\
\cline { 3 - 4 } & & $\begin{array}{l}\text { Alerting } \\
\text { systems }\end{array}$ & $\begin{array}{l}\text { Preventive } \\
\text { maintenance }\end{array}$ & $\begin{array}{l}\text { Regular maintenance, } \\
\text { Field device examinations }\end{array}$ & $\begin{array}{l}\text { DC motor } \\
\text { Relays }\end{array}$ \\
\cline { 2 - 4 } & & Monitoring & $\begin{array}{l}\text { Periodic } \\
\text { maintenance }\end{array}$ & $\begin{array}{l}\text { Record maintenance, } \\
\text { Event sequence recording }\end{array}$ & \\
\hline
\end{tabular}

\subsection{Evolution of Wireless Networks in Process Automation}

Initially, the ZigBee wireless standard was developed to monitor and control different home automation products. Later, it was extended for specific industrial processes, but it was not suitable for regulatory and emergency classes because of its poor data reliability. ZigBee is highly suitable in monitoring and alerting systems, where energy savings is given priority [36]. The remaining communication protocols were explicitly developed for factory automation applications, where each of them was designated for various industrial application classes. WirelessHART, for example, was designed to support closed-loop supervisory and regulatory applications because of its efficient routing capabilities and high potential communication between multiple field devices to ensure multi-channel frequency hopping [37,38]. ISA100.11a and WIA-PA are intended to provide more flexible coverage over all classes of industrial processes listed in Table 3. All these protocols use IEEE 802.15.4 as a physical standard and have a MAC layer with an equal number of channels.

On the other hand, emergency systems require a latency of not more than $10 \mathrm{~ms}$, reliable data transmission, and mote parity. Thus, for these kinds of systems using a multi-hop network is not a suitable option because of network stability issues [6]. The communication standards examined here were mainly developed for monitoring and control category applications, such as open-loop and alerting systems, as shown in Table 3 . The preferred standards among the existing IWSNs in industries were surveyed in 2012 and 2014; the results are summarized in Table 4 [12]. The results indicated that one out of four users preferred WirelessHART, even though it faced a slight decline in the number of adopters. ISA100.11a has attracted adopters, which has resulted in a marginal growth in its implementation. The remaining wireless standards adopted among industrial users are WIA-PA, ZigBee, and Factory Automation. This gives WirelessHART a clear lead for use in the process automation industry $[39,40]$. 
Table 4. Preferred IWSN standards [12].

\begin{tabular}{lcc}
\hline \multicolumn{1}{c}{ Wireless Standard } & $\mathbf{2 0 1 2} \mathbf{( \% )}$ & $\mathbf{2 0 1 4} \mathbf{( \% )}$ \\
\hline WirelessHART & 27 & 25 \\
ISA 100.11a & 10 & 11 \\
Hybrid & 22 & 16 \\
Others (WIA-PA and ZigBee) & 23 & 28 \\
Factory Automation & 13 & 13 \\
\hline
\end{tabular}

\section{Industrial Applications of WirelessHART}

This section gives a brief introduction to the WirelessHART protocol, its typical network structure, and different OSI layers usage. Furthermore, a detailed review of the application of WirelessHART for industrial process monitoring and control in both simulation and real-time environments will be discussed.

\subsection{WirelessHART}

The evolution of the HART protocol is shown diagrammatically in Figure 5. From the figure, it can be seen that since 1988, with only around 4 million wired devices, the standard has incorporated devices such as digital control valves and controllers with HART6 by 2002. By 2007, EDDL and wireless technology were integrated into the latest version of the HART protocol (HART7), released as WirelessHART (IEC 62591), which is the first wireless communication protocol to adopt an over $2.4 \mathrm{GHz}$ radio frequency channel in the IEEE 802.15.4 for industrial process control applications [41].

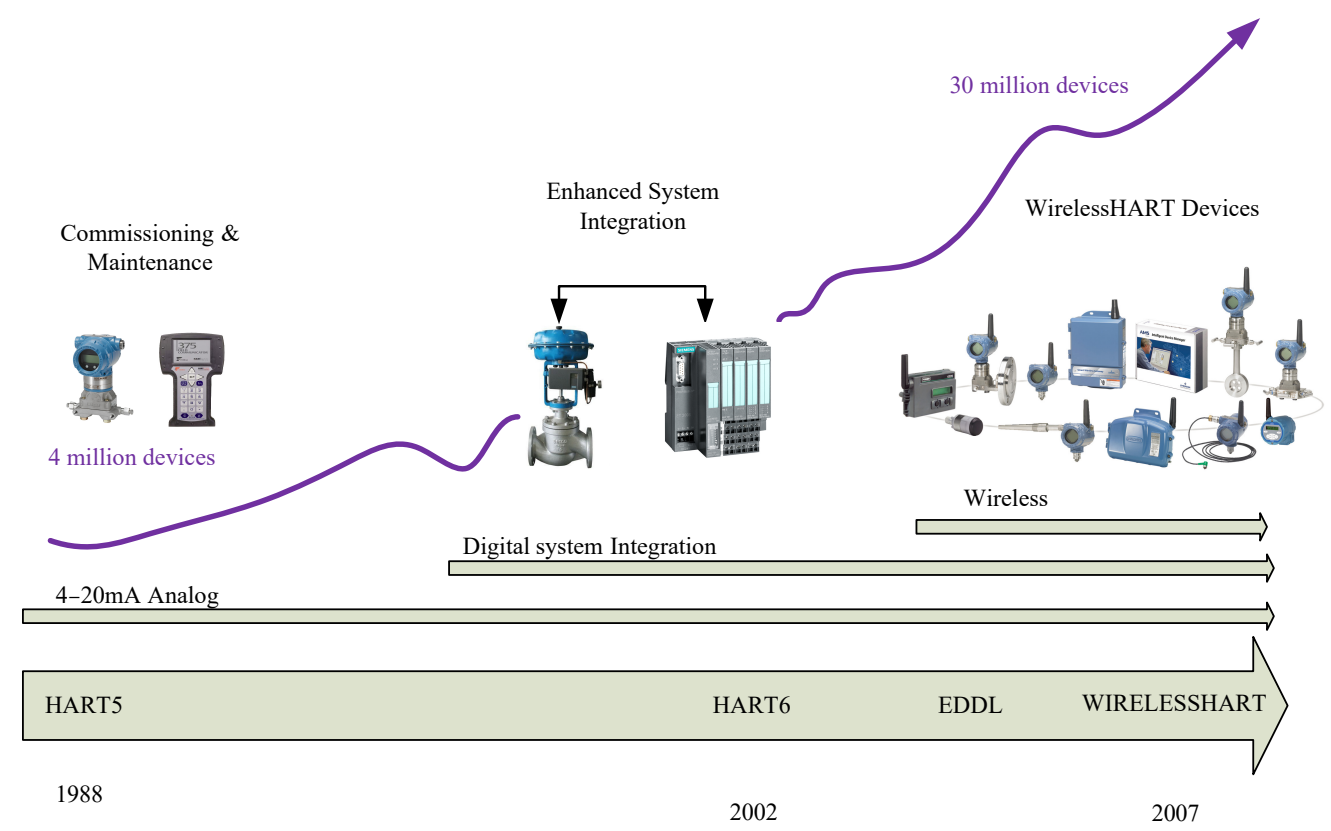

Figure 5. Evolution of the HART protocol [14].

WirelessHART, being based on the traditional HART protocol, has already gained wide patronage in the industry due to the necessity of demand in the open international standard that suits industrial requirements. The latest version (version 2) of the WirelessHART protocol was approved by the International Electrotechnical Commission in 2016. The standard possesses some new updated features, such as:

- Wireless mesh networking;

- Time synchronization and stamping;

- $\quad$ Network and transport layer;

- Security encryption and decryption; 
- Enhanced burst mode messaging;

- Pipes for high-speed file transfer.

The WirelessHART communication protocol utilizes only five layers of the OSI model out of the seven layers. Figure 6 shows the usage of different OSI layers between the conventional wired HART and the WirelessHART protocols. The five OSI layers used by WirelessHART are the physical layer, the data link layer, the network layer, the transport layer, and the application layer. Routing, communication scheduling, and corresponding signal generation are handled by the central network manager. Further detailed discussion of the various OSI layers of WirelessHART and other IWSN communication protocols can be found in $[6,42]$.
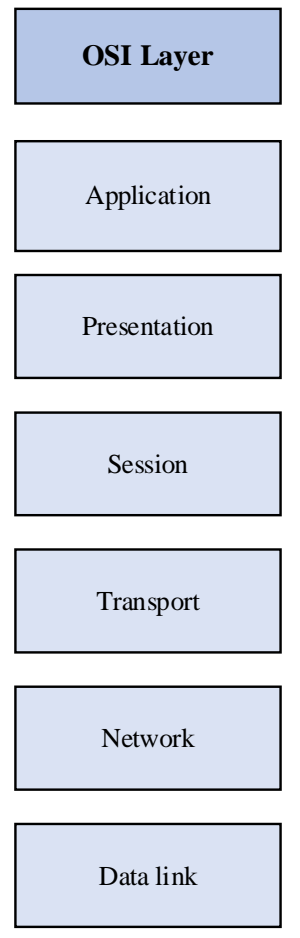

Physical

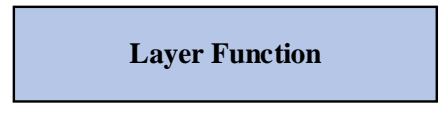

Providing network capable applications for the user

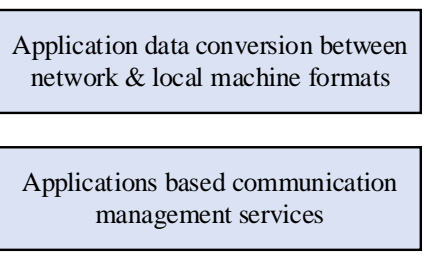

Providing network independent, transparent message transfer

End to End Packets Routing,

Resolving Network Addresses

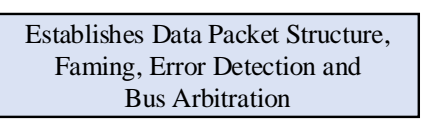

Mechanical/Electrical connection, Transmits Raw Bit Stream

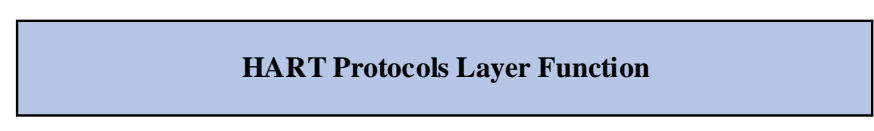

Command oriented, Predefined data types and Application procedures

Auto segmented transfer of large data sets, Reliable stream transport, Negotiated segment sizes

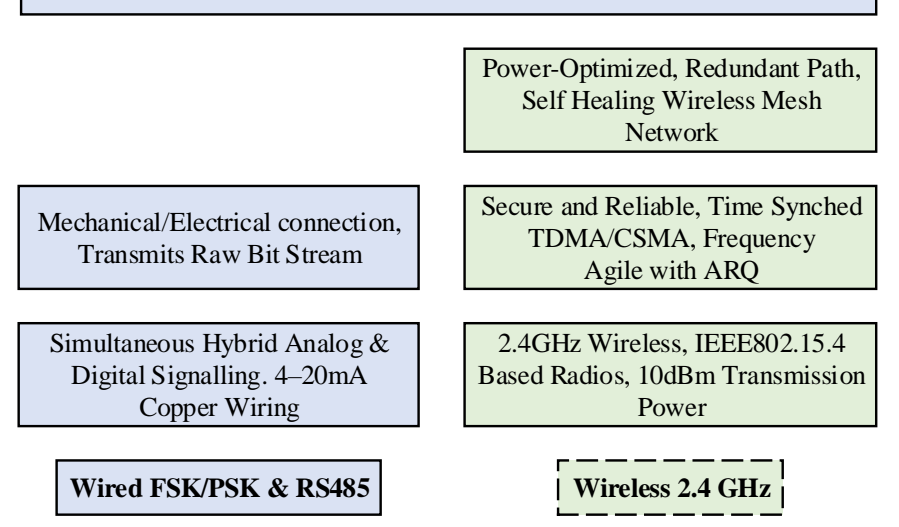

Figure 6. OSI layer of the conventional wired HART and the WirelessHART protocols [43].

An added advantage of WirelessHART is that it can be extended to control the process rather than simply monitor it. Wireless local area network (WLAN), Bluetooth, ZigBee, and Internet Protocol Version 6 (IPV6) are not extensively adopted for industrial wireless applications because of their limitations in controlling capabilities. At present, two of the most widely used industrial international wireless standards are WirelessHART and ISA100 Wireless [44,45]. Among these two, WirelessHART leads with more than 30 million installed field devices, and it is projected that this figure will reach over 46 million by 2021 [46]. Hence, there will be very little or no need for training the plant operators to start using the WirelessHART. Based on its flexibility, interoperability, simplicity, and acceptability, the WirelessHART has many advantageous over the ISA 100.11a standard. Simultaneously, the ISA 100.11a standard is yet to gain approval from the International Electrotechnical Commission (IEC). This has given WirelessHART supremacy in industry [47]. Both standards aim at non-critical wireless applications for control and monitoring purposes. 
Nevertheless, WirelessHART is generally preferred by industries since its legacy wired HART communication protocol was once the dominant and most widely adopted protocol in industrial field devices. Additionally, converting existing wired HART field devices to wireless ones is less costly and there is no need for additional sensor components [48].

The WirelessHART network control system (WHNCS) structure is shown in Figure 7. There are five essential elements present in the WHNCS, namely:

1. Field device: connected to the industrial process plant.

2. Wireless handheld: employed for diagnostics, device configuration, and calibration from a remote location.

3. Gateway: acts as a bridging device to connect host applications and field devices.

4. Network manager: accountable for configuring the network, scheduling, routing, and managing communication.

5. Security manager: managing and allocating security encryption keys and keeping track of authorized devices to connect to the network.

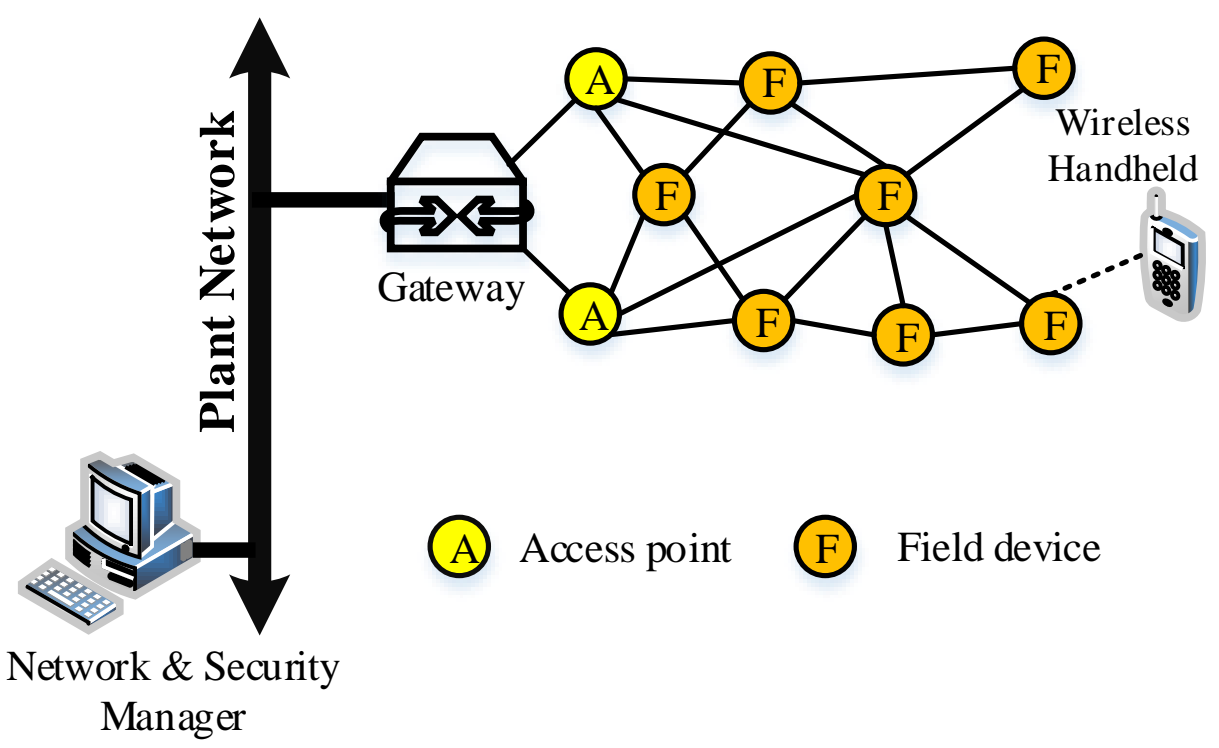

Figure 7. WirelessHART network structure.

\subsection{Simulation Environment}

After the emergence of WirelessHART as the first wireless standard for monitoring and controlling industrial applications, attempts were made to evaluate them in a simulation environment using network simulators, hardware-in-the-loop simulator combined with Matlab, and LABVIEW. Jouni et al. [49] first acquired the patent for WirelessHART communication to control a field device in an industrial process using a cellular communication system. Here, the control system receives data from an internet-connected field device with a diagnostic system connected to it. This method of transmission increases the time delay and is prone to security threats. Later, improvements to security and co-existence with IEEE 802.11g networks were proposed in [50]. Their results validated the network's adaptive frequency hopping ability, rejected high packet loss channels, and blacklisted them to improve reliable data transfer. They concluded that security measures still need to be improved to counter denial-of-service attacks.

Numerous researchers carried out various analyses of protocol development, performance, interoperability, and simulation investigations for process control during the WirelessHART establishment period to understand its effectiveness [51-53]. The initial attempt to use WirelessHART for control-oriented processes started with the development of TrueTime, a Matlab/Simulink-based wireless simulation toolbox specifically designed to support WirelessHART [54]. This modified TrueTime toolbox was used by researchers to simulate a closed-loop process control system in the WirelessHART standard with various packet losses, clock drifts, and delay compensation conditions [55-57]. Communication 
scheduling and controller design methodologies were combined to form a co-design technique to minimize control systems communication latency when using the WirelessHART standard. This method addresses the real-time issues in end-to-end data reliability, packet scheduling, packet loss/drop, and controller performance [58]. A WirelessHART-based simulator focusing on industrial process control application is presented in [59]. This simulator utilizes all 15 channels available in the communication standard for effective scheduling and data transfer to avoid network interference by using multi-hop communication.

WirelessHART's network performance was evaluated against a hybrid simulation approach using COOJA in the Contiki operating system, with particular attention given to its efficient memory and time slotting. Though this method supports the handling of multiple industrial systems, it only supports one data argument. Other essential parameters, such as network management, communication scheduling, flash memory usage, and WirelessHART compliant security layer implementation have not been adequately addressed [60]. An improved co-design simulation technique using an interference model of the process was coded in OMNET++, which is used in TrueTime-Matlab/Simulink [61]. The simulation was conducted for monitoring and controlling the DC servomotor over a WirelessHART network with a conventional PI controller in a closed-loop process. In this model, prominent factors such as multipath fading, noise from the environment, signal interference, and line of sight are not considered, which makes the network reliability questionable. In [62], a hybrid control-oriented approach using WirelessHART in NCS with a source routing configuration to achieve asymptotic and exponential stability under some constraints is presented. In this research, important communication constraints such as stochastic time delay, interference, and packet drop are not examined.

In [11], a simulation using Fast Sampling Wired Link Contention in a WirelessHART network control system with conventional PID is presented to improve the link reliability. Link delay and packet dropout correlation factors are used to address its impact on the closed-loop control performance. They improved the system efficiency by adopting an exponentially weighted moving average (EWMA) filter to remove the packet collisions. In [63], a formation of a distributed WirelessHART network is created by adopting field-level scheduling through a time window slotted allocation. This properly scheduled transmission reduced the power consumption up to $85 \%$ and enhanced the network scalability in comparison with the centralized method. Furthermore, an additional detailed discussion of the WirelessHART simulation by various researchers with their controllers, field devices (virtual nodes in the case of the simulation), and network structures is presented in Table 5.

\subsection{Real-Time Implementation}

Song et al. [64] initiated research on applying WirelessHART in real-time industrial process control and demonstrated their results. The researchers used a modified Freescale $1321 x E v k$ toolkit written in the ANSI C language and created a super-frame time slot configuration for the hosted devices. Simple data scheduling and transmission between the field devices were carried out to indicate the possibility of monitoring and data transfer using the WirelessHART Network. In [65], multiple control strategies for WirelessHART network devices are proposed-namely, (1) controlling through the host, which supports complete control; (2) controlling through the field, which supports partial control; and (3) controlling through the gateway, which supports full control and has less latency compared to all the other approaches. They used the WirelessHART temperature transmitter to transmit and acknowledge the data transmission through the gateway without controlling the process. Real-time experimentation on the distillation column pressure and steam flow was conducted to prove that control over WirelessHART is possible [66]. The process was controlled using a conventional PID controller in both cases to maintain the process set-point. The results proved that WirelessHART transmitters improved the accuracy and performed as reliably as the wired communication without signal filters. Additionally, wireless transmitters are not affected by ground loops, which often affects wired field devices. LabVIEW-based WirelessHART experimentation was conducted to study the effect of 
packet loss on the network control system stability [67]. Multiple industrial communication protocols were compared regarding the gradual increase in the loss probability of data packets from 0 to $100 \%$ to understand their impacts on a network control system's stability.

Table 5. Summary of WirelessHART for monitoring and control applications in the simulation environment.

\begin{tabular}{|c|c|c|c|c|c|c|c|c|}
\hline Ref. & Process & Field device & $\mathbf{T}$ & ST & $\mathrm{C}$ & Mo & $\begin{array}{l}\text { Challenges } \\
\text { Addressed }\end{array}$ & Results \\
\hline$[50]$ & \multirow{3}{*}{$\begin{array}{l}\text { Network } \\
\text { analysis }\end{array}$} & $\begin{array}{l}\text { Temperature } \\
\text { and Pressure } \\
\text { Sensors }\end{array}$ & $\mathrm{M}$ & $\begin{array}{l}\text { Network } \\
\text { simulator } \\
\text { (NS-1) }\end{array}$ & - & SI & $\begin{array}{l}\text { Security } \\
\text { (Signal } \\
\text { Jamming), } \\
\text { Interoperability }\end{array}$ & $\begin{array}{l}\text { WirelessHART and } \\
\text { WLAN coexistence } \\
\text { investigation and network } \\
\text { performance examination }\end{array}$ \\
\hline [51] & & $\begin{array}{l}\text { Emerson } \\
\text { Smart } \\
\text { Wireless } \\
\text { Gateway }\end{array}$ & S & $\begin{array}{l}\text { Emerson } \\
\text { (AMS Snap-on) }\end{array}$ & - & RT & Packet loss & $\begin{array}{l}\text { Data scheduling } \\
\text { and routing analysis for } \\
\text { packet drop mitigation }\end{array}$ \\
\hline [52] & & Sensor nodes & $\mathrm{M}$ & $\begin{array}{l}\text { Network } \\
\text { simulator (NS-2) }\end{array}$ & - & SI & $\begin{array}{l}\text { Latency, } \\
\text { Noise }\end{array}$ & $\begin{array}{l}\text { Effects of packet error rate } \\
\text { and packet drop analysis }\end{array}$ \\
\hline$[53]$ & $\begin{array}{l}\text { Sensor node } \\
\text { networking } \\
\text { experiment }\end{array}$ & $\begin{array}{l}\text { Temperature } \\
\text { sensor, } \\
\text { XDM2510HE } \\
\text { Dust network } \\
\text { gateway }\end{array}$ & $\begin{array}{l}\mathrm{L}, \\
\mathrm{M}, \\
\mathrm{S}\end{array}$ & $\begin{array}{l}\text { WirelessHART } \\
\text { network } \\
\text { simulator }\end{array}$ & - & $\begin{array}{l}\text { SI, } \\
\text { RT }\end{array}$ & $\begin{array}{l}\text { Signal } \\
\text { reliability, } \\
\text { Latency }\end{array}$ & $\begin{array}{l}\text { WirelessHART network } \\
\text { for Dense Reader } \\
\text { Environment in industrial } \\
\text { monitoring }\end{array}$ \\
\hline$[56]$ & $\begin{array}{l}\text { Laboratory } \\
\text { scale open } \\
\text { loop process }\end{array}$ & $\begin{array}{l}\mathrm{ABB} \\
\mathrm{AC} 800 \mathrm{M}\end{array}$ & $\mathrm{M}$ & $\begin{array}{l}\text { TrueTime } \\
\text { with MATLAB }\end{array}$ & $\begin{array}{l}\text { PI, } \\
\text { PPI }\end{array}$ & SI & Latency & $\begin{array}{l}\text { Reduced the problems } \\
\text { caused by clock drift }\end{array}$ \\
\hline$[55]$ & $\begin{array}{l}\text { DC Motor } \\
\text { control }\end{array}$ & Sensor nodes & M & $\begin{array}{l}\text { TrueTime } \\
\text { with MATLAB }\end{array}$ & PD & SI & $\begin{array}{l}\text { Packet loss, } \\
\text { Channel } \\
\text { hopping }\end{array}$ & $\begin{array}{l}\text { WirelessHART } \\
\text { implementation } \\
\text { for sluggish processes }\end{array}$ \\
\hline$[58]$ & $\begin{array}{l}\text { Level } \\
\text { Process }\end{array}$ & Sensor nodes & $\mathrm{M}$ & $\begin{array}{l}\text { Jitterbug } \\
\text { toolbox }\end{array}$ & LQG & SI & $\begin{array}{l}\text { Data } \\
\text { reliability }\end{array}$ & $\begin{array}{l}\text { Improving the network } \\
\text { reliability and controller } \\
\text { design }\end{array}$ \\
\hline
\end{tabular}

T, topology; L, linear; M, mesh; S, star; C, controller; Mo, model of research; ST, simulation tool; SI, simulation; RT, real time.

The PIDPlus algorithm, an improved variant of the conventional PID controller, was employed to take care of slow process updates, packet loss in the communication channel, and non-periodic measurement updates encountered by WirelessHART transmitters [68]. Two other studies using a PID controller with a Kalman filter and Smith predictor were conducted to compare it with the PIDPlus algorithm. The PID with the Kalman filter had a better performance in terms of integral absolute error (IAE). Developments for monitoring and controlling the dividing wall column using event-based model predictive control (MPC) were carried out in [69]. MPC outperformed the PID controller, with faster handling and better compensation for the external disturbances. It suffered from network-induced delay and the implementation complexity increased due to the greater number of tunable parameters. Experimentation with an internal model control (IMC) aimed to investigate the disturbance rejection and set-point tracking capabilities in an industrial-scale pilot process plant. IMC showed a better performance in set-point tracking and overshoot reduction than the PID controller, but when the system order increased the IMC had a slower rise time and increased peak overshoot, which caused the system to settle as equal PID. In [14], the Smith predictor-based filtered predictive PI (FPPI) controller was analyzed in an attempt to compensate for the model mismatch and high-frequency noise issues faced by IMC. Additionally, this controller possessed useful time-delay prediction capabilities to handle stochastic systems. This controller has a simple design structure and has the same number of tunable parameters as the conventional PID controller, which led to its easy implementation and robust performance. Figure 8 shows a comparison of the IAE values 
for different controllers in the WirelessHART network for various industrial processes. Meanwhile, the tunable parameters possessed by the different controllers discussed above are shown in Table 6 [70].

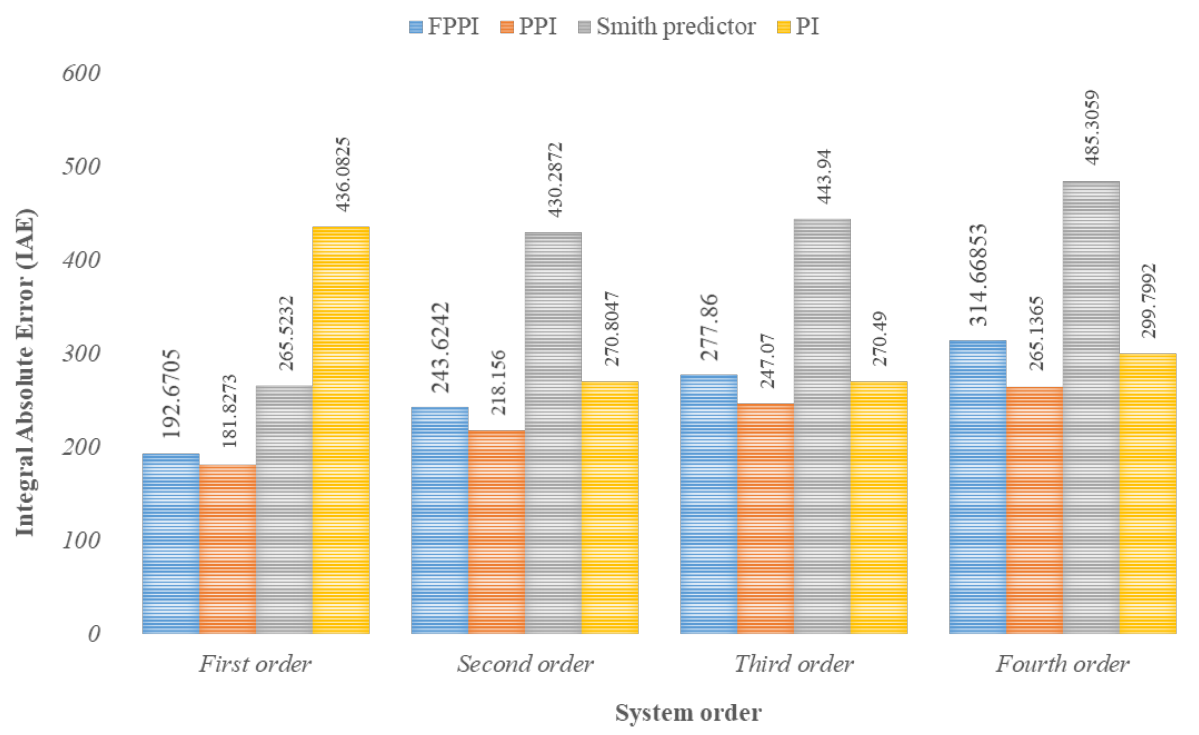

Figure 8. IAE values of various controllers in WirelessHART network [14].

Table 6. Tunable parameters of various controllers [70].

\begin{tabular}{lcccccc}
\hline \multicolumn{1}{c}{ Controller } & \multicolumn{3}{c}{ Model Parameters } & \multicolumn{3}{c}{ Controller Parameters } \\
\hline PI & - & - & - & $K_{c}$ & $T_{i}$ & - \\
FOPI & - & - & - & $K_{c}$ & $T_{i}$ & $\lambda$ \\
PPI & - & - & $L_{p}$ & $K_{c}$ & $T_{i}$ & - \\
FPPI & - & $T_{f}$ & $L_{p}$ & $K_{c}$ & $T_{i}$ & \\
FOPPI & - & - & - & $K_{c}$ & $T_{i}$ & $\lambda$ \\
Smith predictor & $K$ & $T$ & $L_{p}$ & $K_{c}$ & $T_{i}$ & - \\
IMC & $K$ & $T$ & $L_{p}$ & - & $T_{c l}$ & - \\
\hline
\end{tabular}

The parameters discussed above are some of the major contributions towards the real-time implementation of WirelessHART in process control. A detailed study of the real-time implementation of WirelessHART in different controllers, industrial applications, topologies, software tools, and other parameters is given in Table 7 . The majority of the papers concentrated primarily on overcoming the problems of latency and data reliability.

Table 7. Summary of WirelessHART for monitoring and control applications.

\begin{tabular}{|c|c|c|c|c|c|c|c|c|}
\hline Ref. & Process & Field Device & $\mathbf{T}$ & ST & $\mathrm{C}$ & Mo & $\begin{array}{l}\text { Challenges } \\
\text { Addressed }\end{array}$ & Results \\
\hline [59] & $\begin{array}{l}\text { Actuator to } \\
\text { sensor } \\
\text { communication }\end{array}$ & Sensor nodes & - & $\begin{array}{l}\text { WirelessHART } \\
\text { simulator in } \\
\text { MATLAB }\end{array}$ & - & SI & $\begin{array}{l}\text { Reliability } \\
\text { (Interference } \\
\text { minimization) }\end{array}$ & $\begin{array}{l}\text { WirelessHART } \\
\text { simulator for large } \\
\text { scale networks }\end{array}$ \\
\hline [61] & $\begin{array}{l}\text { DC servo } \\
\text { motor control }\end{array}$ & Virtual sensor nodes & M & $\begin{array}{l}\text { TrueTime } \\
\text { with } \\
\text { OMNET++ } \\
\text { in MATLAB }\end{array}$ & PI & SI & Interoperability & $\begin{array}{l}\text { Improving } \\
\text { coexistence } \\
\text { management for } \\
\text { WirelessHART and } \\
\text { ISA100.11a }\end{array}$ \\
\hline
\end{tabular}


Table 7. Cont.

\begin{tabular}{|c|c|c|c|c|c|c|c|c|}
\hline Ref. & Process & Field Device & $\mathbf{T}$ & ST & $\mathrm{C}$ & Mo & $\begin{array}{l}\text { Challenges } \\
\text { Addressed }\end{array}$ & Results \\
\hline [62] & $\begin{array}{l}\text { Unstable batch } \\
\text { reactor }\end{array}$ & Sensor nodes & $\mathrm{L}$ & $\begin{array}{l}\text { Network } \\
\text { simulator }\end{array}$ & PI & SI & Stability & $\begin{array}{l}\text { Stabilized routing } \\
\text { configuration using } \\
\text { a hybrid approach for } \\
\text { non-linear systems } \\
\text { and time-varying } \\
\text { transmissions }\end{array}$ \\
\hline [11] & $\begin{array}{l}\text { Network } \\
\text { analysis on } \\
\text { industrial } \\
\text { process models }\end{array}$ & $\begin{array}{l}\text { XDM2510H } \\
\text { WirelessHART } \\
\text { RF Module }\end{array}$ & - & $\begin{array}{l}\text { WirelessHART } \\
\text { simulator in } \\
\text { MATLAB }\end{array}$ & PID & SI & $\begin{array}{l}\text { Link } \\
\text { reliability, } \\
\text { Latency }\end{array}$ & $\begin{array}{l}\text { Effective design } \\
\text { of an EWMA } \\
\text { filter to mitigate } \\
\text { packet dropout } \\
\text { and link delay }\end{array}$ \\
\hline [63] & $\begin{array}{l}\text { Test bed of } \\
\text { TelosB mote }\end{array}$ & $\begin{array}{l}\text { Chipcon } \\
\text { CC2420 }\end{array}$ & M & $\begin{array}{l}\text { TinyOS 2.2, } \\
\text { TOSSIM }\end{array}$ & - & SI & $\begin{array}{l}\text { Link } \\
\text { reliability, } \\
\text { Channel } \\
\text { Hopping }\end{array}$ & $\begin{array}{l}\text { Time window } \\
\text { allocation for } \\
\text { real-time scheduling } \\
\text { to reduce resource } \\
\text { usage and enhancing } \\
\text { the scalability }\end{array}$ \\
\hline$[64]$ & $\begin{array}{l}\text { Laboratory } \\
\text { scale testing }\end{array}$ & $\begin{array}{l}\text { Freescale } \\
\text { MC1321x } \\
\text { evaluation } \\
\text { toolkit }\end{array}$ & M & $\begin{array}{l}\text { ANSI C in } \\
\text { HCS08 }\end{array}$ & - & $\mathrm{RT}$ & Security & $\begin{array}{l}\text { Data scheduling } \\
\text { and transmission } \\
\text { between the field } \\
\text { devices to indicate } \\
\text { the possibility of } \\
\text { monitoring and } \\
\text { data transfer }\end{array}$ \\
\hline [65] & $\begin{array}{l}\text { WirelessHART } \\
\text { test bench }\end{array}$ & $\begin{array}{l}\text { Rosemount } \\
648 \mathrm{TT}\end{array}$ & M & Wi-Analys & - & $\mathrm{RT}$ & - & $\begin{array}{l}\text { Achieving data } \\
\text { transfer between } \\
\text { the field nodes } \\
\text { and the controller } \\
\text { via gateway }\end{array}$ \\
\hline [66] & $\begin{array}{l}\text { Steam flow } \\
\text { and pressure } \\
\text { of Distillation } \\
\text { column }\end{array}$ & $\begin{array}{l}\text { Raschig } \\
\text { Jaeger } \\
\text { RSP-250 }\end{array}$ & - & & PID & $\mathrm{RT}$ & $\begin{array}{l}\text { Latency } \\
\text { analysis, } \\
\text { Data } \\
\text { reliability }\end{array}$ & $\begin{array}{l}\text { To control the } \\
\text { industrial process } \\
\text { in WirelessHART } \\
\text { network }\end{array}$ \\
\hline [67] & $\begin{array}{l}\text { DC servo } \\
\text { motor }\end{array}$ & $\begin{array}{l}\text { NI-DAC } \\
\text { control cards }\end{array}$ & - & LabVIEW & $\mathrm{P}$ & $\mathrm{RT}$ & $\begin{array}{l}\text { Delay, } \\
\text { Packet loss }\end{array}$ & $\begin{array}{l}\text { Performance } \\
\text { investigation } \\
\text { for the effect } \\
\text { of different } \\
\text { networks on the } \\
\text { control with a } \\
\text { simulation study } \\
\text { for fixed packet } \\
\text { loss case }\end{array}$ \\
\hline [68] & $\begin{array}{l}\text { Industrial } \\
\text { process plant }\end{array}$ & - & - & $\begin{array}{l}\text { DeltaV } \\
\text { control } \\
\text { system }\end{array}$ & $\begin{array}{l}\text { PID, } \\
\text { PIDPlus }\end{array}$ & $\mathrm{RT}$ & $\begin{array}{l}\text { Data } \\
\text { reliability }\end{array}$ & $\begin{array}{l}\text { Designing a } \\
\text { control strategy } \\
\text { for non-periodic } \\
\text { measurement } \\
\text { updates from } \\
\text { the processes }\end{array}$ \\
\hline
\end{tabular}


Table 7. Cont.

\begin{tabular}{|c|c|c|c|c|c|c|c|c|}
\hline Ref. & Process & Field Device & $\mathbf{T}$ & ST & $\mathrm{C}$ & Mo & $\begin{array}{l}\text { Challenges } \\
\text { Addressed }\end{array}$ & Results \\
\hline [14] & $\begin{array}{l}\text { Pressure } \\
\text { process plant }\end{array}$ & $\begin{array}{l}\text { Linear tech } \\
\text { Smart Mesh } \\
\text { WirelessHART } \\
\text { (XG2510HE } \\
\text { gateway and } \\
\text { XDM2510H } \\
\text { node) }\end{array}$ & $\mathrm{M}$ & MATLAB & $\begin{array}{l}\text { PI, } \\
\text { PPI, } \\
\text { FPPI }\end{array}$ & $\begin{array}{l}\text { SI, } \\
\text { RT }\end{array}$ & $\begin{array}{l}\text { Predictive } \\
\text { characteristics, } \\
\text { Packet delay }\end{array}$ & $\begin{array}{l}\text { Controlling a } \\
\text { real-time process } \\
\text { plant even in } \\
\text { presence of noise } \\
\text { and packet delay }\end{array}$ \\
\hline [69] & $\begin{array}{l}\text { Distillation } \\
\text { column } \\
\text { control }\end{array}$ & $\begin{array}{l}\text { Wireless } \\
\text { field } \\
\text { devices }\end{array}$ & - & $\begin{array}{l}\text { DeltaV } \\
\text { PredictPro }\end{array}$ & $\begin{array}{l}\text { PID, } \\
\text { MPC }\end{array}$ & RT & $\begin{array}{l}\text { Predictive } \\
\text { characteristics }\end{array}$ & $\begin{array}{l}\text { To control the } \\
\text { industrial process } \\
\text { with real-time } \\
\text { data prediction } \\
\text { for packet loss } \\
\text { compensation }\end{array}$ \\
\hline [71] & \multirow{2}{*}{$\begin{array}{l}\text { Network } \\
\text { simulation }\end{array}$} & Sensor nodes & - & $\begin{array}{l}\text { TrueTime } \\
\text { with } \\
\text { MATLAB }\end{array}$ & PID & SI & Packet drop & $\begin{array}{l}\text { Simulation study on } \\
\text { wired and wireless } \\
\text { networked control } \\
\text { system under various } \\
\text { packet loss conditions }\end{array}$ \\
\hline [72] & & $\begin{array}{l}\text { WirelessHART } \\
\text { mote } \\
\text { (DC9003A) } \\
\text { Eterna Interface } \\
\text { card } \\
\text { (DC9006A) }\end{array}$ & $\mathrm{M}$ & $\begin{array}{l}\text { SmartMesh } \\
\text { API Explorer } \\
\text { stack with } \\
\text { MATLAB }\end{array}$ & PID & SI & $\begin{array}{l}\text { Network } \\
\text { delay }\end{array}$ & $\begin{array}{l}\text { Network induced } \\
\text { delays measurement } \\
\text { technique and its } \\
\text { effects on a pilot } \\
\text { process plant }\end{array}$ \\
\hline [48] & $\begin{array}{l}\text { Level } \\
\text { Flow, } \\
\text { Heat and } \\
\text { pressure } \\
\text { process } \\
\text { plants }\end{array}$ & $\begin{array}{l}\text { Linear } \\
\text { Technology } \\
\text { WirelessHART } \\
\text { Modules }\end{array}$ & $\mathrm{M}$ & MATLAB & $\begin{array}{l}\text { PID, } \\
\text { MPC }\end{array}$ & $\begin{array}{l}\text { SI, } \\
\text { RT }\end{array}$ & $\begin{array}{l}\text { Latency, } \\
\text { Data } \\
\text { reliability }\end{array}$ & $\begin{array}{l}\text { Even under model } \\
\text { mismatch and packet } \\
\text { delay variation, the } \\
\text { controller is designed } \\
\text { to keep the process } \\
\text { control loop as } \\
\text { a stable one }\end{array}$ \\
\hline [73] & $\begin{array}{l}\text { Network } \\
\text { analysis }\end{array}$ & $\begin{array}{l}\text { AwiaTech } \\
\text { WirelessHART } \\
\text { evaluation kit }\end{array}$ & $\begin{array}{c}\mathrm{L}, \\
\mathrm{M}, \\
\mathrm{S}\end{array}$ & $\begin{array}{l}\text { AwiaTech } \\
\text { WirelessHART } \\
\text { simulator }\end{array}$ & - & $\begin{array}{l}\text { SI, } \\
\text { RT }\end{array}$ & $\begin{array}{l}\text { Latency, } \\
\text { Data } \\
\text { reliability, } \\
\text { Interference }\end{array}$ & $\begin{array}{l}\text { Examined the } \\
\text { joining time for } \\
\text { each node and } \\
\text { their effect on } \\
\text { the distance } \\
\text { between them }\end{array}$ \\
\hline [37] & $\begin{array}{l}\text { Industrial } \\
\text { processes } \\
\text { transfer } \\
\text { functions }\end{array}$ & $\begin{array}{l}\text { Linear tech } \\
\text { Smart Mesh } \\
\text { WirelessHART } \\
\text { (XG2510HE } \\
\text { gateway, } \\
\text { XDM2510H } \\
\text { node) }\end{array}$ & - & $\begin{array}{l}\text { WirelessHART } \\
\text { hardware-in- } \\
\text { the-loop } \\
\text { simulator with } \\
\text { MATLAB }\end{array}$ & $\begin{array}{c}\text { PI, Smith } \\
\text { predictor, } \\
\text { Set-point } \\
\text { weighted PI }\end{array}$ & $\begin{array}{l}\text { SI, } \\
\text { RT }\end{array}$ & $\begin{array}{l}\text { Stochastic } \\
\text { delay, } \\
\text { Noise }\end{array}$ & $\begin{array}{l}\text { Controller } \\
\text { implementation } \\
\text { in WirelessHART } \\
\text { network under } \\
\text { model mismatch, } \\
\text { stochastic delay, } \\
\text { and noise } \\
\text { conditions }\end{array}$ \\
\hline [74] & $\begin{array}{l}\text { Flow } \\
\text { process }\end{array}$ & $\begin{array}{l}\text { SmartMesh } \\
\text { WirelessHART } \\
\text { kit }\end{array}$ & - & $\begin{array}{l}\text { SmartMesh } \\
\text { API Explorer } \\
\text { stack with } \\
\text { MATLAB }\end{array}$ & $\begin{array}{c}\text { PI, } \\
\text { PID, } \\
\text { Fuzzy PID }\end{array}$ & RT & $\begin{array}{l}\text { Network } \\
\text { delay }\end{array}$ & $\begin{array}{l}\text { Investigations on the } \\
\text { effects of using } \\
\text { wired and } \\
\text { WirelessHART } \\
\text { motes on the control } \\
\text { performance on } \\
\text { pilot process plant }\end{array}$ \\
\hline
\end{tabular}


Table 7. Cont.

\begin{tabular}{|c|c|c|c|c|c|c|c|c|}
\hline Ref. & Process & Field Device & $\mathbf{T}$ & ST & C & Mo & $\begin{array}{l}\text { Challenges } \\
\text { Addressed }\end{array}$ & Results \\
\hline$[75]$ & $\begin{array}{l}\text { Tennessee } \\
\text { Eastman } \\
\text { (TE) Plant }\end{array}$ & Sensor nodes & M & $\begin{array}{l}\text { OMNET++ } \\
\text { wireless } \\
\text { network } \\
\text { simulator }\end{array}$ & - & SI & $\begin{array}{l}\text { Packet errors, } \\
\text { Packet drop, } \\
\text { Link failure }\end{array}$ & $\begin{array}{l}\text { Performance study } \\
\text { of WirelessHART } \\
\text { networks on a TE } \\
\text { plant in the presence } \\
\text { of packet errors and } \\
\text { packet drop }\end{array}$ \\
\hline [76] & $\begin{array}{l}\text { Flow and } \\
\text { Level } \\
\text { process }\end{array}$ & $\begin{array}{l}\text { WirelessTHUM } \\
\text { adaptor }\end{array}$ & - & $\begin{array}{l}\text { LabVIEW } \\
\text { and } \\
\text { Emerson } \\
\text { Smart } \\
\text { Wireless } \\
\text { Gateway }\end{array}$ & PID & RT & $\begin{array}{l}\text { Network } \\
\text { delay }\end{array}$ & $\begin{array}{l}\text { Cascaded PID controller is } \\
\text { designed and experimented to } \\
\text { handle network induced delay } \\
\text { and disturbance }\end{array}$ \\
\hline [77] & $\begin{array}{l}\text { Teleoperated } \\
\text { system }\end{array}$ & - & - & $\begin{array}{l}\text { MATLAB } \\
\text { and } \\
\text { SystemC }\end{array}$ & - & SI & $\begin{array}{l}\text { Packet loss, } \\
\text { Delay }\end{array}$ & $\begin{array}{l}\text { Networked control } \\
\text { systems co-simulations } \\
\text { for time synchronization } \\
\text { and error tracking }\end{array}$ \\
\hline$[78]$ & $\begin{array}{l}\text { Batch } \\
\text { reactor }\end{array}$ & - & M & $\begin{array}{l}\text { WirelessHART } \\
\text { simulator }\end{array}$ & LQR & SI & $\begin{array}{l}\text { Packet } \\
\text { scheduling } \\
\text { and } \\
\text { transmission }\end{array}$ & $\begin{array}{l}\text { Scheduling and routing in a } \\
\text { WirelessHART networked } \\
\text { control system with } \\
\text { controller co-design }\end{array}$ \\
\hline$[79]$ & $\begin{array}{l}\text { Valve } \\
\text { actuation } \\
\text { control }\end{array}$ & $\begin{array}{l}\text { Emerson } \\
1420 \mathrm{~A}\end{array}$ & $\mathrm{M}$ & $\begin{array}{l}\text { HART UDP } \\
\text { interface with } \\
\mathrm{C}++\end{array}$ & PID & RT & Latency & $\begin{array}{l}\text { Investigation of control } \\
\text { valve positioning using a } \\
\text { PID controller in a } \\
\text { WirelessHART } \\
\text { environment }\end{array}$ \\
\hline [80] & $\begin{array}{l}\text { Wireless } \\
\text { sensor } \\
\text { network } \\
\text { testbed } \\
\end{array}$ & $\begin{array}{l}\text { TelosB motes } \\
\text { with Chipcon } \\
\text { CC } 2420\end{array}$ & $\mathrm{M}$ & $\begin{array}{l}\text { WirelessHART } \\
\text { network } \\
\text { simulator }\end{array}$ & - & SI & $\begin{array}{l}\text { Latency, } \\
\text { Interference }\end{array}$ & $\begin{array}{l}\text { Determining the packet } \\
\text { schedulability of real-time } \\
\text { data flow based on } \\
\text { new network model map }\end{array}$ \\
\hline$[81]$ & & $\begin{array}{l}\text { Virtual } \\
\text { sensor nodes }\end{array}$ & Random & MATLAB & - & SI & $\begin{array}{l}\text { Data } \\
\text { scheduling, } \\
\text { Latency }\end{array}$ & $\begin{array}{l}\text { Examination of the problem } \\
\text { in joint transmission } \\
\text { scheduling and channel } \\
\text { allocation to minimize } \\
\text { end-to-end delay }\end{array}$ \\
\hline [82] & $\begin{array}{l}\text { Network } \\
\text { analysis }\end{array}$ & & $\begin{array}{c}\mathrm{S}, \\
\mathrm{M}, \\
\mathrm{T}\end{array}$ & $\begin{array}{l}\text { NS-2 simulator } \\
\text { and } \\
\text { OPNET simulator }\end{array}$ & - & SI & $\begin{array}{l}\text { Delay, } \\
\text { Energy } \\
\text { consumption }\end{array}$ & $\begin{array}{l}\text { Performance comparison of } \\
\text { different industrial wireless } \\
\text { sensor network protocols }\end{array}$ \\
\hline [83] & & $\begin{array}{l}\text { Rosemount } \\
-1420 \\
\text { Rosemount } \\
-3051 S\end{array}$ & $\begin{array}{l}\mathrm{S} \\
\mathrm{M}\end{array}$ & $\begin{array}{l}\text { DeltaV } \\
\text { and } \\
\text { Emerson Smart } \\
\text { Wireless Gateway }\end{array}$ & PID & $\begin{array}{l}\text { SI, } \\
\text { RT }\end{array}$ & $\begin{array}{l}\text { Latency, } \\
\text { Packet drop, } \\
\text { Noise }\end{array}$ & $\begin{array}{l}\text { New controller design } \\
\text { to overcome network } \\
\text { delay and packet dropout even } \\
\text { in a noisy environment }\end{array}$ \\
\hline$[84]$ & $\begin{array}{l}\text { Industrial } \\
\text { process } \\
\text { transfer } \\
\text { functions }\end{array}$ & $\begin{array}{l}\text { WirelessHART } \\
\text { mote } \\
\text { (DC9003A) } \\
\text { Eterna Interface } \\
\text { card } \\
\text { (DC9006A) } \\
\end{array}$ & M & $\begin{array}{l}\text { SmartMesh } \\
\text { API Explorer } \\
\text { with MATLAB }\end{array}$ & $\begin{array}{c}\text { Fuzzy } \\
\text { Set-point } \\
\text { weighted PI }\end{array}$ & SI & $\begin{array}{l}\text { Latency, } \\
\text { Packet } \\
\text { drop }\end{array}$ & $\begin{array}{l}\text { Mitigation of network } \\
\text { delay and packet drop } \\
\text { in the closed-loop } \\
\text { process using a Fuzzy } \\
\text { Adaptive Set-point } \\
\text { Weighting Controller }\end{array}$ \\
\hline [85] & $\begin{array}{l}\text { Flow } \\
\text { process }\end{array}$ & $\begin{array}{l}\text { SmartMesh } \\
\text { WirelessHART } \\
\text { kit, } \\
\text { T-click board } \\
\text { with Arduino }\end{array}$ & - & MATLAB & $\begin{array}{c}\text { PI, } \\
\text { Smith } \\
\text { predictor, } \\
\text { Fuzzy PID }\end{array}$ & $\mathrm{RT}$ & $\begin{array}{l}\text { Packet } \\
\text { delay, } \\
\text { Latency }\end{array}$ & $\begin{array}{l}\text { Implementation of locally } \\
\text { developed WirelessHART } \\
\text { adaptors in the pilot } \\
\text { process plant and } \\
\text { performance comparison } \\
\text { of various controllers }\end{array}$ \\
\hline [86] & $\begin{array}{l}\text { Industrial } \\
\text { process } \\
\text { transfer } \\
\text { functions }\end{array}$ & $\begin{array}{l}\text { Virtual } \\
\text { sensor nodes }\end{array}$ & M & Python & PID & SI & $\begin{array}{l}\text { Network } \\
\text { load, } \\
\text { Link } \\
\text { reliability, } \\
\text { Latency }\end{array}$ & $\begin{array}{l}\text { Examination of variable } \\
\text { payload message length } \\
\text { effects in round trip } \\
\text { delay measurements }\end{array}$ \\
\hline
\end{tabular}


Table 7. Cont.

\begin{tabular}{|c|c|c|c|c|c|c|c|c|}
\hline Ref. & Process & Field Device & $\mathrm{T}$ & ST & $\mathrm{C}$ & Mo & $\begin{array}{l}\text { Challenges } \\
\text { Addressed }\end{array}$ & Results \\
\hline [87] & $\begin{array}{l}\text { Transfer } \\
\text { function } \\
\text { of thermal } \\
\text { chamber } \\
\text { process }\end{array}$ & $\begin{array}{l}\text { Linear tech } \\
\text { Smart Mesh } \\
\text { WirelessHART } \\
\text { kit (XG2510HE } \\
\text { gateway, } \\
\text { XDM2510H } \\
\text { node) }\end{array}$ & - & MATLAB & $\begin{array}{c}\text { Smith } \\
\text { predictor, } \\
\text { PI, } \\
\text { PPI }\end{array}$ & SI & $\begin{array}{l}\text { Delay, } \\
\text { Noise, } \\
\text { Disturbance }\end{array}$ & $\begin{array}{l}\text { New controller } \\
\text { performance analysis } \\
\text { over a variable network } \\
\text { delay, external noise, } \\
\text { and process dead-time }\end{array}$ \\
\hline [88] & $\begin{array}{l}\text { Valve } \\
\text { control }\end{array}$ & $\begin{array}{l}\text { Rosemount 702, } \\
\text { Fisher } 4320 \\
\text { on/off valve, } \\
\text { AwiaTech } \\
\text { WirelessHART } \\
\text { Evaluation Kit }\end{array}$ & $S$ & $\begin{array}{l}\text { Emerson } \\
\text { Process } \\
\text { Management }\end{array}$ & $\mathrm{P}$ & RT & $\begin{array}{l}\text { Latency, } \\
\text { Data } \\
\text { Reliability, } \\
\text { Signal } \\
\text { Interference }\end{array}$ & $\begin{array}{l}\text { Comparative study of } \\
\text { WirelessHART and } \\
\text { wired Foundation } \\
\text { Fieldbus for } \\
\text { valve control }\end{array}$ \\
\hline [89] & $\begin{array}{l}\text { Flow } \\
\text { process }\end{array}$ & $\begin{array}{l}\text { Fisher } 4320 \\
\text { wireless } \\
\text { position } \\
\text { transmitter }\end{array}$ & & $\begin{array}{l}\text { DeltaV } \\
\text { control } \\
\text { system }\end{array}$ & $\begin{array}{c}\text { PID, } \\
\text { PIDPlus }\end{array}$ & RT & Delay & $\begin{array}{l}\text { Experimentation of } \\
\text { valve position control } \\
\text { using a PIDPlus controller } \\
\text { in a WirelessHART } \\
\text { network for the } \\
\text { flow process }\end{array}$ \\
\hline [90] & $\begin{array}{l}\text { Production } \\
\text { decision } \\
\text { and } \\
\text { supporting } \\
\text { system } \\
\text { (PDSS) }\end{array}$ & $\begin{array}{l}34 \text { TelosB } \\
\text { motes with } \\
\text { Chipcon } \\
\text { CC2410 }\end{array}$ & M & $\begin{array}{l}\text { TinyOS } 2.1 \\
\text { with } \\
\text { CC2420x } \\
\text { radio driver }\end{array}$ & LQR & RT & $\begin{array}{l}\text { Latency, } \\
\text { Data } \\
\text { transmission }\end{array}$ & $\begin{array}{l}\text { Co-design strategies for } \\
\text { a small industrial } \\
\text { Cyber-Physical } \\
\text { System to enhance } \\
\text { communication reliability }\end{array}$ \\
\hline [91] & $\begin{array}{l}\text { Two } \\
\text { tank } \\
\text { system }\end{array}$ & $\begin{array}{l}\text { Emerson } \\
\text { Smart } \\
\text { Wireless } \\
\text { Gateway kit }\end{array}$ & - & LabVIEW & - & RT & Delay & $\begin{array}{l}\text { Modeling and flow } \\
\text { measurement of a } \\
\text { coupled tank process } \\
\text { based on Laplace } \\
\text { transformation with } \\
\text { simple linear } \\
\text { optimizations to reduce } \\
\text { sudden load disturbance } \\
\text { and errors }\end{array}$ \\
\hline
\end{tabular}

\section{Challenges and Design Requirements}

The deployment of wireless motes comes with its own requirements and challenges because of the significant differences between the office environment and the industrial environment. For example, in the industrial environment, the deployed wireless network must have the ability to support the low latency with secure data communication in critical processes. For inherent safety, these networks must possess a high fault-tolerance capability and have highly reliable data transmission in order to meet the industrial requirements [92,93]. Additionally, low-power wireless motes need to be developed, since they have to operate for more extended periods between major turnarounds considering the harsh conditions [94]. In the future, the implementation of non-conventional energypowered mote installation is anticipated to increase in industrial and process automation because it dramatically reduces power blackouts, avoids the problem of battery replacement, and has a smaller carbon footprint [27].

The deployed WirelessHART network should be aware of unpredictable environmental parameters such as temperature, moisture, gas level, pressure, and vibrations in the environment where the field devices are located. Wireless mote signals could be severely 
delayed due to various circumstances, such as interference with multiple frequency bands, reflections from the surrounding walls, external noise, signal attenuation due to leaked gases, and vibrations produced by heavy machinery $[95,96]$. Most of the problems stated above will affect their deployment because a minor interruption can make the network less reliable and may lead to catastrophic failure in the process. Other major influencing parameters in the WirelessHART network are briefly discussed in the following.

\subsection{Security}

Security is one of the prime challenges in WHNCS deployment in the process control industry. Irrespective of critical and non-critical processes, they are always prone to security threats [97]. To achieve secure transmission, the network should be aware of denial-ofservice (DoS) attacks and cyber-attacks from outside networks [98]. Both active and passive attacks may take place, such as snooping on transmission signals, the modification of signal information, signal interruption, data flooding, and re-routing the network paths. These must all be considered in the design phase $[3,99]$. Due to resource limitations, security protocols have to be balanced against other quality of service (QoS) performance requirements [100]. Data encryption, data authentication, and cluster-based private data aggregation (CPDA) techniques will minimize security attacks in the network. Sensor network encryption protocol (SNEP), localized encryption and authentication protocol (LEAP), and random key pre-distribution (RKP) are some of the most effective techniques to block malicious attacks such as data flooding, information spoofing, and data transit attacks [101].

\subsection{Reliability and Interference}

In the industrial environment, compared with traditional wired networks, WHNCS has low reliable communication because of interferences such as noise, electromagnetic radiation, multipath distortion, temperature, and humidity from nearby industrial equipment and surrounding walls $[47,102]$. These situations result in packet loss and delay, making the adoption of WHNCS in the industrial environment as a challenging one. Signal parameters such as the link quality indicator (LQI) and radio signal strength indicator (RSSI) can be utilized to identify the link quality and reliable data transmission $[103,104]$. Other methods, such as path re-routing [39], efficient re-transmission techniques [105], link failure analysis, and redundancy devices [106], will be helpful to improve the reliability and data transmission. This might result in additional transmission overhead that wastes mote energy and makes the network congested, which in turn affects the reliable transmission of data [107]. In the future, the necessity of efficient routing algorithms in multi-hop communication with optimized memory utilization is expected to improve the processing power and reliability of motes.

\subsection{Latency}

Closed-loop processes continuously require real-time reliable sensor data to keep the process stable. If the network experiences any delay in data transmission larger than a specified time, the data cannot be used for effective control actions. Therefore, new critical data must be transmitted through the network to a sink instead of retrying all transmissions [37]. Additionally, packet delay and transmission failure result in the performance degradation of the WHNCS [48]. Forward error correcting, multi-path and multi-SPEED routing protocol (MMSPEED), and routing protocol for low-power and lossy networks (RPL), can be used to minimize the number of retransmission attempts to mitigate the network failure delay [39]. Another possible solution is designing a controller with a predictive nature to compensate the network and plant delay, which will minimize the impacts of unavoidable stochastic delay in the control loop [14,108]. 


\subsection{Interoperability}

Though industrial process plants contain multiple field devices which support different wireless communication protocols, all the IWSN protocols use the standard $2.4 \mathrm{GHz}$ ISM frequency band as a physical layer. Recent significant improvements were made in the network layer, MAC layer, and physical layer to enhance these standards coexistence. These advancements are based on improving the routing methods, MAC layer restructuring, device sleep scheduling, and transmission power control. However, there is still a much wider gap that needs to be reduced to make all the IWSNs comply with each other, and carrying out more research on real-time scheduling for WHNCS is a high priority $[109,110]$. Interoperability will also reduce the necessity of procuring new devices for adopting new standards in the industrial environment [111].

\subsection{Cost Effectiveness and Resource Utilization}

The prime motivation for transitioning from wired to wireless solutions is the low cost requirements for deploying and installing wireless field devices. IWSN is intended to provide increased productivity, reduced maintenance, and decreased operating costs [112]. Some wireless sensor solutions cost less than $\$ 200$ for deployment at the field level, while the same wired device installation costs can be doubled because of additional laying and wiring costs [113]. Most WirelessHART field devices are compact and small in size, which is an added advantage when encountering factory space problems, helping to make installing a large-scale network of nodes easier [114]. However, this compactness reduces the computational capabilities because of the limited memory and battery power supply. This situation also causes the WHNCS to suffer from a limited operational range in harsh industrial environments, which makes real-time data delivery challenging [115].

\subsection{Power Consumption and Battery lifetime}

One of the most critical parameters to be considered when adopting WHNCS is energy efficiency. Almost all wireless motes support battery operation capabilities with a low power consumption [116]. In order to conserve the energy of the motes, clustering algorithms such as energy-efficient sleep awake aware (EESAA), sleep-wake energy-efficient distributed (SEED), and hybrid energy-efficient distributed (HEED) can be adopted to minimize redundant transmission to achieve energy efficiency and improve data collection $[117,118]$. Adaptive free-shape clustering (AFC) is an emerging technique that greatly minimizes power consumption and increases the network lifetime [119]. Other non-conventional power generation methods such as photovoltaics, wind power, and thermoelectric conversion can be combined with WirelessHART field devices to achieve longterm operation without the need of any human intervention [82,120]. A detailed survey of energy harvesting in IWSN is discussed in [121]. Thus, power consumption and battery lifetime are a significant bottleneck while using the sensor nodes for their extended features at the field level.

\subsection{Fault Tolerance}

Network failures, mote power dropout, and stochastic delay in the WHNCS are unpredictable. Failure of one or more motes could result in the collapse of the entire process. Such characteristics have led to the development of various techniques, such as energy aware routing for low-energy ad hoc sensor networks (EAR-LEAHSN), the energy-aware QoS routing protocol (EQoSR), the multi-level route-aware clustering algorithm (MRLC), and the distributed clustering-based multipath algorithm (DCM), to provide standby redundant paths/devices to support multi-hopping [122,123]. Using these techniques in real time comes with complications, such as increased energy consumption due to the multiple copies of data transmission to sink node, greater bandwidth utilization for reliable data, continuous alternate path-finding, and complex data reconstruction processes [124]. 


\subsection{Data Accessibility}

Data accessibility and management are some of the most frequently occurring issues in the WHNCS because of the limited storage availability and may even lead to end-toend packet delay [81]. Sensors installed in particular industrial environments can send identical data, which often leads to unnecessary data aggregation and the need to process a massive amount of metadata. To avoid this problem, motes can be designed so as to filter the non-critical data using predetermined conditions or distributed source coding (DSC) to compress the raw data before sending them to the sink [125]. These methods can significantly improve data scalability, device versatility, and battery life [126]. Alternative techniques, such as low-energy adaptive clustering hierarchical (LEACH), power efficient gathering in sensor information systems (PEGASIS), and multi-hop routing protocol with unequal clustering (MRPUC), can be combined into clusters in order to overcome the problem of data transmission for a large group of nodes [127]. However, the research trends show that an increase in the network size increases the computational and communication overhead of the WHNCS.

\subsection{Autonomous and Predictive Characteristics}

Unexpected network/mote collapse results in catastrophic failures in the closed-loop process, which creates the need for the independent operation of motes as autonomous and self-organizing devices without any human intervention [128]. In this situation, the addition or removal of the deployed motes may lead to network partitioning. WirelessHART has the advantage of mesh networking, which enables it to form a self-organizing network coordination framework (SoNCF). The framework can independently create multiple packet time slots in a self-organized manner for better data prediction throughput [129]. The implementation of autonomous nodes comes with greater energy consumption and more extensive data aggregation due to their continuous monitoring and transmission. Most WHNCS challenges and design goals are interlinked with one another, causing them to evolve continuously with new technological advancements to acquire the same promising performance as the wired networks.

\section{Summary and Conclusions}

This survey presents the application of WirelessHART from the perspective of industrial monitoring and control in both simulations and real-time environments. This paper also examines the disparity between industrial needs and the currently available technology, which creates challenges for the performance of WHNCS. The design goals and application challenges faced by WirelessHART were comprehensively addressed. Additionally, possible research developmental solutions, which may solve most of the above-stated problems, are given in Table 8 to improve its performance and increase the chance of adoption by the process control industries. Additionally, though WirelessHART is the leader in its field, IWSN is still evolving. It is too early to suggest which wireless protocol will most impact the process control industry in the future. More factors, such as interoperability between the various standards, scalability, security, reliability, and realtime updates with the limited latency range prescribed by industrial requirements, were also kept in mind while enhancing the standards. To overcome the above challenges and requirements, an efficient WirelessHART network can be introduced to all process industries and will hopefully eventually replace the existing wired legacy systems. However, the current WHNCS development rate is too slow to reach its maximum potential and needs continuous improvements. It also requires collaborative progress with other IWSN protocols to be widely accepted in the industrial process control. 
Table 8. WirelessHART challenges and possible research and development solutions.

\begin{tabular}{|c|c|c|}
\hline Challenges & Limitations/ Problems & Possible Research and Development Solutions \\
\hline Battery & $\begin{array}{l}\text { Limited power supply } \\
\text { Price is proportional to capacity and durability }\end{array}$ & $\begin{array}{l}\text { Sleep scheduling }[63,78] \\
\text { Passive data transfer }[130,131] \\
\text { Effective data redundancy }[78]\end{array}$ \\
\hline Memory & $\begin{array}{l}\text { Limited memory power } \\
\text { for complex processes }\end{array}$ & $\begin{array}{l}\text { Memory optimization and } \\
\text { additional memory allocation }[63,132,133]\end{array}$ \\
\hline $\begin{array}{l}\text { Computational } \\
\text { power }\end{array}$ & Confined traditional processor & $\begin{array}{l}\text { Usage of modern SRAM and DRAM [134] } \\
\text { Current generation processor co-design }[58,78,90]\end{array}$ \\
\hline Data transmission & $\begin{array}{l}\text { Interference } \\
\text { Overlapping }\end{array}$ & $\begin{array}{l}\text { Adaptive channeling } \\
\text { and multi-hop communication }[135,136] \\
\text { Distribute routing protocol }[39,137]\end{array}$ \\
\hline Delay & $\begin{array}{l}\text { Process instability } \\
\text { Stochastic delay }\end{array}$ & $\begin{array}{l}\text { Slotted retransmission } \\
\text { and scheduled transmissions [138] } \\
\text { Priority data access [139] } \\
\text { Fault tolerant }[53,127]\end{array}$ \\
\hline Network traffic & $\begin{array}{l}\text { Random transmission } \\
\text { Interference and overlapping } \\
\text { Data aggregation }\end{array}$ & $\begin{array}{l}\text { Channel scheduling and } \\
\text { TDMA slotting [51,81] } \\
\text { Estimation and filtering [37,135] } \\
\text { (e.g., Kalman, Particle) }\end{array}$ \\
\hline Controlling & $\begin{array}{l}\text { Delay } \\
\text { Network/ mote failure }\end{array}$ & $\begin{array}{l}\text { Multi-hop transmission }[135,140] \\
\text { Delay compensators }[85,87] \\
\text { Model-based predictive controllers }[14,48]\end{array}$ \\
\hline Security & $\begin{array}{l}\text { DoS, QoS } \\
\text { Data theft } \\
\text { Channel flooding } \\
\text { Hacking } \\
\text { Signal interference }\end{array}$ & $\begin{array}{l}\text { Data and Network encryption and authentication }[71,141,142] \\
\text { Cryptographic keying }[100,143]\end{array}$ \\
\hline Interoperability & $\begin{array}{l}\text { Inadequate standardization } \\
\text { Existing numerous protocols }\end{array}$ & $\begin{array}{l}\text { IPv6-based enhancement }[47,144] \\
\text { Interoperable node and network development }[50,61,145]\end{array}$ \\
\hline
\end{tabular}

Author Contributions: Conceptualization, literature review, and detailed analysis, P.A.M.D.; proofreading, guidance, and regular feedback, F.A.H., R.I., K.B., F.A.K.; writing-original draft preparation, P.A.M.D., K.B.; writing-review and editing, P.A.M.D., K.B.; supervision and project administration, F.A.H., R.I., K.B., F.A.K. All authors have read and agreed to the published version of the manuscript.

Funding: This work was supported by Yayasan Universiti Teknologi PETRONAS fundamental research grant YUTP 015LC0-045.

Institutional Review Board Statement: Not applicable.

Informed Consent Statement: Not applicable.

Data Availability Statement: Not applicable.

Conflicts of Interest: The authors declare no conflict of interest.

\section{Abbreviations}

DoS Denial-of-Service

FPPI Filtered Predictive PI

FoPPI Fractional-order Predictive PI

HART Highway Addressable Remote Transducer

IWSN Industrial Wireless Sensor Network

IAE Integral Absolute Error

IMC Internal Model Control

MAC Medium Access Control

MPC Model Predictive Control

PI Proportional Integral

PPI Predictive PI

PID Proportional Integral Derivative

TITO Two Input Two Output

UWSN Underwater Wireless Sensor Networks

WIA-PA Wireless network for Industrial Automation-Process Automation

WHNCS WirelessHART Network Control Systems 


\section{References}

1. Åström, K.J.; Murray, R.M. Feedback Systems: An Introduction for Scientists and Engineers; Princeton University Press: Princeton, NJ, USA,

2021.

2. Garpinger, O.; Hägglund, T.; Åström, K.J. Performance and robustness trade-offs in PID control. J. Process Control 2014, 24, 568-577. [CrossRef]

3. Raza, M.; Aslam, N.; Le-Minh, H.; Hussain, S.; Cao, Y.; Khan, N.M. A critical analysis of research potential, challenges, and future directives in industrial wireless sensor networks. IEEE Commun. Surv. Tutor. 2017, 20, 39-95. [CrossRef]

4. Raposo, D.; Rodrigues, A.; Sinche, S.; Sá Silva, J.; Boavida, F. Industrial IoT monitoring: Technologies and architecture proposal. Sensors 2018, 18, 3568. [CrossRef]

5. Zou, Y.; Zhu, J.; Wang, X.; Hanzo, L. A survey on wireless security: Technical challenges, recent advances, and future trends. Proc. IEEE 2016, 104, 1727-1765. [CrossRef]

6. Wang, Q.; Jiang, J. Comparative examination on architecture and protocol of industrial wireless sensor network standards. IEEE Commun. Surv. Tutor. 2016, 18, 2197-2219. [CrossRef]

7. Salam, H.A.; Khan, B.M. IWSN-standards, challenges and future. IEEE Potentials 2016, 35, 9-16. [CrossRef]

8. Luvisotto, M.; Pang, Z.; Dzung, D. Ultra high performance wireless control for critical applications: Challenges and directions. IEEE Trans. Ind. Inform. 2016, 13, 1448-1459. [CrossRef]

9. Menezes, M. Wireless HART ${ }^{\circledR}$ Minimizes Cost of New Energy Measurements. Energy Eng. 2015, 112, 69-77. [CrossRef]

10. Blevins, T.; Chen, D.; Nixon, M.; Wojsznis, W. Wireless Control Foundation: Continuous and Discrete Control for the Process Industry; International Society of Automation:Research Triangle Park, NC, USA 2015; Volume 4.

11. Chung, T.D.; Ibrahim, R.B.; Asirvadam, V.S.; Saad, N.B.; Hassan, S.M. Adopting ewma filter on a fast sampling wired link contention in wirelesshart control system. IEEE Trans. Instrum. Meas. 2016, 65, 836-845. [CrossRef]

12. Hatler, M. Industrial wireless sensor networks: Trends and developments. Retrieved 2013, 11, 2013.

13. Gavel, S.; Raghuvanshi, A.S.; Tiwari, S. A multilevel hybrid anomaly detection scheme for industrial wireless sensor networks. Int. J. Netw. Manag. 2020, e2144, doi:10.1002/nem.2144. [CrossRef]

14. Hassan, S.M.; Ibrahim, R.; Saad, N.; Bingi, K.; Asirvadam, V.S. Hybrid PID Based Predictive Control Strategies for WirelessHART Networked Control Systems; Springer Nature: Berlin/Heidelberg, Germany, 2020; Volume 293,

15. Park, P.; Ergen, S.C.; Fischione, C.; Lu, C.; Johansson, K.H. Wireless network design for control systems: A survey. IEEE Commun Surv. Tutor. 2017, 20, 978-1013. [CrossRef]

16. Ovsthus, K.; Kristensen, L.M. An industrial perspective on wireless sensor networks-A survey of requirements, protocols, and challenges. IEEE Commun. Surv. Tutor. 2014, 16, 1391-1412.

17. Li, X.; Li, D.; Wan, J.; Vasilakos, A.V.; Lai, C.F.; Wang, S. A review of industrial wireless networks in the context of industry 4.0 Wirel. Netw. 2017, 23, 23-41. [CrossRef]

18. Kandris, D.; Nakas, C.; Vomvas, D.; Koulouras, G. Applications of wireless sensor networks: An up-to-date survey. Appl. Syst. Innov. 2020, 3, 14. [CrossRef]

19. Mishra, A.; Agrawal, D.P. Evaluation of Suitability of Current Industrial Standards in Designing Control Applications for Internet of Things Healthcare Sensor Networks. J. Sens. Actuator Netw. 2019, 8, 54. [CrossRef]

20. Ghayvat, H.; Mukhopadhyay, S.; Gui, X.; Suryadevara, N. WSN-and IOT-based smart homes and their extension to smart buildings. Sensors 2015, 15, 10350-10379. [CrossRef] [PubMed]

21. Croce, S.; Tondini, S. Urban Microclimate Monitoring and Modeling through an Open-Source Distributed Network of Wireless Low-Cost Sensors and Numerical Simulations; Engineering Proceedings; Multidisciplinary Digital Publishing Institute: Basel, Switzerland 2020; Volume 2, p. 18.

22. Baire, M.; Melis, A.; Lodi, M.B.; Dachena, C.; Fanti, A.; Farris, S.; Pisanu, T.; Mazzarella, G. WSN Hardware for Automotive Applications: Preliminary Results for the Case of Public Transportation. Electronics 2019, 8, 1483. [CrossRef]

23. Islam, S.; Park, S.Y.; Zheng, S.; Han, S.; Park, S.M. Supervisory Control for Wireless Networked Power Converters in Residential Applications. Energies 2019, 12, 1911. [CrossRef]

24. Fadel, E.; Gungor, V.C.; Nassef, L.; Akkari, N.; Malik, M.A.; Almasri, S.; Akyildiz, I.F. A survey on wireless sensor networks for smart grid. Comput. Commun. 2015, 71, 22-33. [CrossRef]

25. Tang, X.; Wang, X.; Cattley, R.; Gu, F.; Ball, A.D. Energy harvesting technologies for achieving self-powered wireless sensor networks in machine condition monitoring: A review. Sensors 2018, 18, 4113. [CrossRef]

26. Ullah, R.; Faheem, Y.; Kim, B.S. Energy and congestion-aware routing metric for smart grid AMI networks in smart city. IEEE Access 2017, 5, 13799-13810. [CrossRef]

27. Ojha, T.; Misra, S.; Raghuwanshi, N.S. Wireless sensor networks for agriculture: The state-of-the-art in practice and future challenges. Comput. Electron. Agric. 2015, 118, 66-84. [CrossRef]

28. Baire, M.; Melis, A.; Lodi, M.B.; Tuveri, P.; Dachena, C.; Simone, M.; Fanti, A.; Fumera, G.; Pisanu, T.; Mazzarella, G. A wireless sensors network for monitoring the Carasau bread manufacturing process. Electronics 2019, 8, 1541. [CrossRef] 
29. Fattah, S.; Gani, A.; Ahmedy, I.; Idris, M.Y.I.; Targio Hashem, I.A. A Survey on Underwater Wireless Sensor Networks: Requirements, Taxonomy, Recent Advances, and Open Research Challenges. Sensors 2020, 20, 5393. [CrossRef] [PubMed]

30. Santana Abril, J.; Santana Sosa, G.; Sosa, J.; Bautista, T.; Montiel-Nelson, J.A. A Novel Charging Method for Underwater Batteryless Sensor Node Networks. Sensors 2021, 21, 557. [CrossRef]

31. Al-Turjman, F.M.; Hassanein, H.S.; Ibnkahla, M.A. Efficient deployment of wireless sensor networks targeting environment monitoring applications. Comput. Commun. 2013, 36, 135-148. [CrossRef]

32. Zhao, G. Wireless Sensor Networks for Industrial Process Monitoring and Control: A Survey. Netw. Protoc. Algorithms 2011, 3, 46-63. [CrossRef]

33. Zhao, G.; Imran, M.A.; Pang, Z.; Chen, Z.; Li, L. Toward real-time control in future wireless networks: communication-control co-design. IEEE Commun. Mag. 2018, 57, 138-144. [CrossRef]

34. Sparks, R. Reduce Costs with Wireless Instrumentation, Emerson Process Management; 2009. Available online: https://www. powermag.com/reduce-costs-with-wireless-instrumentation/ (accessed on 7 May 2021)

35. Hassan, S.M.; Ibrahim, R.; Bingi, K.; Chung, T.D.; Saad, N. Application of wireless technology for control: A WirelessHART perspective. Procedia Comput. Sci. 2017, 105, 240-247. [CrossRef]

36. Zand, P.; Chatterjea, S.; Das, K.; Havinga, P. Wireless industrial monitoring and control networks: The journey so far and the road ahead. J. Sens. Actuator Netw. 2012, 1, 123-152. [CrossRef]

37. Hassan, S.M.; Ibrahim, R.; Saad, N.; Asirvadam, V.S.; Bingi, K. Adopting setpoint weighting strategy for WirelessHART networked control systems characterised by stochastic delay. IEEE Access 2017, 5, 25885-25896. [CrossRef]

38. Zand, P.; Mathews, E.; Havinga, P.; Stojanovski, S.; Sisinni, E.; Ferrari, P. Implementation of wirelesshart in the ns-2 simulator and validation of its correctness. Sensors 2014, 14, 8633-8668. [CrossRef]

39. Nobre, M.; Silva, I.; Guedes, L.A. Routing and scheduling algorithms for WirelessHARTNetworks: A survey. Sensors 2015, 15, 9703-9740. [CrossRef]

40. Kobo, H.I.; Abu-Mahfouz, A.M.; Hancke, G.P. A survey on software-defined wireless sensor networks: Challenges and design requirements. IEEE Access 2017, 5, 1872-1899. [CrossRef]

41. Maass, A.I.; Nešić, D.; Postoyan, R.; Dower, P.M.; Varma, V.S. Emulation-based stabilisation of networked control systems over WirelessHART. In Proceedings of the 2017 IEEE 56th Annual Conference on Decision and Control (CDC), Melbourne, VIC, Australia, 12-15 December 2017;

pp. 6628-6633.

42. Oliveira, L.; Rodrigues, J.J.; Kozlov, S.A.; Rabêlo, R.A.; Albuquerque, V.H.C.D. MAC layer protocols for Internet of Things: A survey. Future Internet 2019, 11, 16. [CrossRef]

43. Han, S.; Nixon, M.; Chen, D.; Mok, A.; Muston, P. WirelessHART ${ }^{\mathrm{TM}}$ sensor networks. In Industrial Wireless Sensor Networks; Elsevier: Amsterdam, The Netherlands,

2016; pp. 79-103.

44. Kwon, S.; Jeong, J.; Shon, T. Toward security enhanced provisioning in industrial IoT systems. Sensors 2018, 18, 4372. [CrossRef] [PubMed]

45. Li, J.Q.; Yu, F.R.; Deng, G.; Luo, C.; Ming, Z.; Yan, Q. Industrial internet: A survey on the enabling technologies, applications, and challenges. IEEE Commun. Surv. Tutor. 2017, 19, 1504-1526. [CrossRef]

46. Tramarin, F.; Mok, A.K.; Han, S. Real-time and reliable industrial control over wireless lans: Algorithms, protocols, and future directions. Proc. IEEE 2019, 107, 1027-1052. [CrossRef]

47. Jin, X.; Kong, F.; Kong, L.; Liu, W.; Zeng, P. Reliability and temporality optimization for multiple coexisting WirelessHART networks in industrial environments. IEEE Trans. Ind. Electron. 2017, 64, 6591-6602. [CrossRef]

48. Tran, C.D.; Ibrahim, R.; Asirvadam, V.S.; Saad, N.; Miya, H.S. Internal model control for industrial wireless plant using WirelessHART hardware-in-the-loop simulator. ISA Trans. 2018, 75, 236-246. [CrossRef] [PubMed]

49. Pyotsia, J.; Simula, M.; Cederlof, H. Wireless Control of a Field Device in an Industrial Process, U.S. Patent 7,010,294, 7 March 2006.

50. Petersen, S.; Carlsen, S. Performance evaluation of WirelessHART for factory automation. In Proceedings of the 2009 IEEE Conference on Emerging Technologies \& Factory Automation, Palma de Mallorca, Spain, 22-25 September 2009; pp. 1-9.

51. Winter, J.M.; Kunzel, G.; Muller, I.; Pereira, C.E.; Netto, J.C. Study of routing mechanisms in a WirelessHART network. In Proceedings of the 2013 IEEE International Conference on Industrial Technology (ICIT), Cape Town, South Africa, 25-28 February 2013; pp. 1540-1545.

52. Huang, Q.; Sikora, A.; Groza, V.F.; Zand, P. Simulation \& analysis of WirelessHART nodes for real-time actuator application. In Proceedings of the 2014 IEEE International Instrumentation and Measurement Technology Conference (I2MTC), Montevideo, Uruguay, 12-15 May 2014; pp. 1590-1594.

53. Nawaz, F.; Jeoti, V. Performance assessment of WirelessHART technology for its implementation in dense reader environment. Computing 2016, 98, 257-277. [CrossRef]

54. Cervin, A.; Henriksson, D.; Lincoln, B.; Eker, J.; Arzen, K.E. How does control timing affect performance? Analysis and simulation of timing using Jitterbug and TrueTime. IEEE Control Syst. Mag. 2003, 23, 16-30.

55. De Biasi, M.; Snickars, C.; Landernäs, K.; Isaksson, A. Simulation of process control with WirelessHART networks subject to clock drift. In Proceedings of the 2008 32nd Annual IEEE International Computer Software and Applications Conference, Turku, Finland, 28 July-1 August 2008; pp. 1355-1360. 
56. De Biasi, M.; Snickars, C.; Landernas, K.; Isaksson, A.J. Simulation of process control with WirelessHART networks subject to packet losses. In Proceedings of the 2008 IEEE International Conference on Automation Science and Engineering, Arlington, VA, USA, 23-26 August 2008; pp. 548-553.

57. Snickars, C. Design of a WirelessHART Simulator for Studying Delay Compensation in Networked Control Systems. Masters' Degree Project, KTH Royal Institute of Technology, Stockholm, Sweden 2008. Available online: http://citeseerx.ist.psu.edu/ viewdoc/download?doi=10.1.1.542.1127\&rep=rep1\&type=pdf (accessed on 7 May 2020)

58. Pesonen, J.; Zhang, H.; Soldati, P.; Johansson, M. Methodology and tools for controller-networking codesign in WirelessHART. In Proceedings of the 2009 IEEE Conference on Emerging Technologies \& Factory Automation, Palma de Mallorca, Spain, 22-25 September 2009; pp. 1-8.

59. Shah, K.; Seceleanu, T.; Gidlund, M. Design and implementation of a WirelessHART simulator for process control. In Proceedings of the International Symposium on Industrial Embedded System (SIES), Trento, Italy, 7-9 July 2010; pp. 221-224.

60. Gustafsson, D. Wirelesshart-Implementation and Evaluation on Wireless Sensors. Masters's Thesis, KTH University, Electrical Engineering, Stockholm, Sweden, 2009; pp. 1-39.

61. Ferrari, P.; Flammini, A.; Rizzi, M.; Sisinni, E. Improving simulation of wireless networked control systems based on WirelessHART. Comput. Stand. Interfaces 2013, 35, 605-615. [CrossRef]

62. Maass, A.I.; Nešić, D.; Dower, P.M. A hybrid model of networked control systems implemented on WirelessHART networks under source routing configuration. In Proceedings of the 2016 Australian Control Conference (AuCC), Newcastle, NSW, Australia, 3-4 November 2016; pp. 60-65.

63. Modekurthy, V.P.; Saifullah, A.; Madria, S. DistributedHART: A distributed real-time scheduling system for WirelessHART networks. In Proceedings of the 2019 IEEE Real-Time and Embedded Technology and Applications Symposium (RTAS), Montreal, QC, Canada, 16-18 April 2019; pp. 216-227.

64. Song, J.; Han, S.; Mok, A.; Chen, D.; Lucas, M.; Nixon, M.; Pratt, W. WirelessHART: Applying wireless technology in real-time industrial process control. In Proceedings of the 2008 IEEE Real-Time and Embedded Technology and Applications Symposium, St. Louis, MO, USA, 22-24 April 2008; pp. 377-386.

65. Han, S.; Zhu, X.; Aloysius, K.M.; Nixon, M.; Blevins, T.; Chen, D. Control over WirelessHART network. In Proceedings of the IECON 2010-36th Annual Conference on IEEE Industrial Electronics Society, Glendale, AZ, USA, 7-10 November 2010; pp. 2114-2119.

66. Seibert, F.; Belvins, T. Wireless HART successfully handles control.

Chem. Process. ER-000148-Jan, 2011. Available online: https:/ /www.emerson.com/documents/automation/article-wirelesshartsuccessfully-handles-control-deltav-en-37778.pdf (accessed on 7 May 2020)

67. Mahmoud, M.S.; Sabih, M. Experimental investigations for distributed networked control systems. IEEE Syst. J. 2013, 8, 717-725. [CrossRef]

68. Blevins, T.; Nixon, M.; Wojsznis, W. PID control using wireless measurements. In Proceedings of the 2014 American Control Conference, Portland, OR, USA, 4-6 June 2014; pp. 790-795.

69. Blevins, T.; Wojsznis, W.K.; Nixon, M.J.; Roach, B. Wireless model predictive control applied for dividing wall column control. In Proceedings of the 2016 Second International Conference on Event-based Control, Communication, and Signal Processing (EBCCSP), Krakow, Poland, 13-15 June 2016; pp. 1-7.

70. Devan, P.A.M.; Hussin, F.A.B.; Ibrahim, R.; Bingi, K.; Abdulrab, H.Q. Fractional-Order Predictive PI Controller for Dead-Time Processes With Set-Point and Noise Filtering. IEEE Access 2020, 8, 183759-183773. [CrossRef]

71. Chung, T.D.; Ibrahim, R.B.; Asirvadam, V.S.; Saad, N.B.; Hassan, S.M. Simulation of WirelessHART networked control system with packet dropout. In Proceedings of the 2015 10th Asian Control Conference (ASCC), Kota Kinabalu, Malaysia, 31 May-3 June 2015; pp. 1-6.

72. Chung, T.D.; Ibrahim, R.; Asirvadam, V.S.; Saad, N.; Hassan, S.M. Effect of network induced delays on WirelessHART control system. In Proceedings of the 2016 6th International Conference on Intelligent and Advanced Systems (ICIAS), Kuala Lumpur, Malaysia, 15-17 August 2016; pp. 1-5.

73. Hassan, S.M.; Ibrahim, R.; Saad, N.; Asirvadam, V.S.; Chung, T.D. Implementation of real-time WirelessHART network for control application. In Proceedings of the 2016 6th International Conference on Intelligent and Advanced Systems (ICIAS), Kuala Lumpur, Malaysia, 15-17 August 2016; pp. 1-6.

74. Chien, L.J.; Ibrahim, R.; Hassan, S.M.; Bingi, K.; Supramaniam, T. Comparison Between Wired and WirelessHART Networked PID Control of Process Flow. In Proceedings of the 2018 International Conference on Intelligent and Advanced System (ICIAS), Kuala Lumpur, Malaysia, 13-14 August 2018; pp. 1-5.

75. Liu, Y.; Candell, R.; Lee, K.; Moayeri, N. A simulation framework for industrial wireless networks and process control systems. In Proceedings of the 2016 IEEE World Conference on Factory Communication Systems (WFCS), Aveiro, Portugal, 3-6 May 2016; pp. 1-11.

76. Somkane, P.; Kongratana, V.; Gulpanich, S.; Tipsuwanporn, V.; Wongvanich, N. A study of flow-level cascade control with WirelessHART TM transmitter using LabVIEW. In Proceedings of the 2017 17th International Conference on Control, Automation and Systems (ICCAS), Jeju, Korea, 18-21 October 2017; pp. 856-861. 
77. Quaglia, D.; Muradore, R.; Fiorini, P. A SystemC/MATLAB Co-simulation Tool for Networked Control Systems. In Coordination Control of Distributed Systems; Springer: Berlin/Heidelberg, Germany, 2015; pp. 283-290.

78. Di Girolamo, G.D.; D'Innocenzo, A. Codesign of controller, routing and scheduling in WirelessHART networked control systems. Int. J. Robust Nonlinear Control 2019, 29, 2171-2187. [CrossRef]

79. Soto, V.S.; Muller, I.; Winter, J.M.; Pereira, C.E.; Netto, J.C. Control over wirelesshart network through a host application: A wirelesshart network control proposal. In Proceedings of the 2014 Brazilian Symposium on Computing Systems Engineering, Manaus, Brazil, 3-7 November 2014; pp. 91-96.

80. Saifullah, A.; Xu, Y.; Lu, C.; Chen, Y. End-to-end communication delay analysis in industrial wireless networks. IEEE Trans. Comput. 2014, 64, 1361-1374. [CrossRef]

81. Chen, G.; Cao, X.; Liu, L.; Sun, C.; Cheng, Y. Joint scheduling and channel allocation for end-to-end delay minimization in industrial WirelessHART networks. IEEE Internet Things J. 2018, 6, 2829-2842. [CrossRef]

82. Battsh, J.A.; Sheltami, T.R.; Mhamoud, A.S.H.; Barnawi, A.Y. Performance Evaluation of Industrial Wireless Sensor Network Technologies: ZigBee, WirelessHART, and Isa100. Int. J. Interdiscip. Telecommun. Netw. 2018, 10, 77-97. [CrossRef]

83. Abdullah, H.; Ibrahim, R.; Hassan, S.M.; Chung, T.D. Filtered feedback PID control for WirelessHART networked plant. In Proceedings of the 2016 6th International Conference on Intelligent and Advanced Systems (ICIAS), Kuala Lumpur, Malaysia, 15-17 August 2016; pp. 1-5.

84. Hassan, S.M.; Ibrahim, R.; Saad, N.; Asirvadam, V.S.; Bingi, K.; Chung, T.D. Fuzzy Adaptive Setpoint Weighting Controller for WirelessHART Networked Control Systems. In Wireless Sensor Networks-Insights and Innovations; IntechOpen: London, UK, 2017.

85. Hassan, S.M.; Bingi, K.; Ibrahim, R.; Chein, L.J.; Supramaniam, T. Implementation of flow control over wirelessHART sensor network using wirelessHART adaptors. Indones. J. Electr. Eng. Comput. Sci. 2019, 15, 910-919. [CrossRef]

86. Chung, T.D.; Ibrahim, R.; Asirvadam, V.S.; Saad, N.; Hassan, S.M. Latency analysis of WirelessHART control message with variable payload. In Proceedings of the 2016 2nd IEEE International Symposium on Robotics and Manufacturing Automation (ROMA), Ipoh, Malaysia, 25-27 September 2016; pp. 1-5.

87. Hassan, S.M.; Ibrahim, R.; Saad, N.; Asirvadam, V.S.; Chung, T.D. Predictive PI controller for wireless control system with variable network delay and disturbance. In Proceedings of the 2016 2nd IEEE International Symposium on Robotics and Manufacturing Automation (ROMA), Ipoh, Malaysia, 25-27 September 2016; pp. 1-6.

88. Zhu, X.; Lin, T.; Han, S.; Mok, A.; Chen, D.; Nixon, M.; Rotvold, E. Measuring WirelessHART against wired fieldbus for control. In Proceedings of the IEEE 10th INTERNATIONAL Conference on Industrial Informatics, Beijing, China, 25-27 July 2012; pp. 270-275.

89. Blevins, T.; Nixon, M.; Wojsznis, W. Event based control applied to wireless throttling valves. In Proceedings of the 2015 International Conference on Event-based Control, Communication, and Signal Processing (EBCCSP), Krakow, Poland, 1719 June 2015; pp. 1-6.

90. Liu, J.; Lin, J. Design optimization of WirelessHART networks in Cyber-Physical Systems. J. Syst. Archit. 2019, 97, 168-184. [CrossRef]

91. Wongvanich, N.; Pongsumpun, P. Simplified Modeling Approach to Characterize Sudden Load Disturbances in WirelessHART FOPDT Systems. In Proceedings of the 2018 15th International Conference on Control, Automation, Robotics and Vision (ICARCV), Singapore, 18-21 November 2018; pp. 1567-1572.

92. Huang, V.K.; Pang, Z.; Chen, C.J.A.; Tsang, K.F. New trends in the practical deployment of industrial wireless: From noncritical to critical use cases. IEEE Ind. Electron. Mag. 2018, 12, 50-58. [CrossRef]

93. Igarashi, Y.; Nakano, R.; Wakamiya, N. A Polling-Based Transmission Scheme Using a Network Traffic Uniformity Metric for Industrial IoT Applications. Sensors 2019, 19, 187. [CrossRef]

94. Suto, K.; Nishiyama, H.; Kato, N.; Huang, C.W. An energy-efficient and delay-aware wireless computing system for industrial wireless sensor networks. IEEE Access 2015, 3, 1026-1035. [CrossRef]

95. Seferagić, A.; Famaey, J.; De Poorter, E.; Hoebeke, J. Survey on wireless technology trade-offs for the industrial internet of things. Sensors 2020, 20, 488. [CrossRef] [PubMed]

96. Queiroz, D.V.; Alencar, M.S.; Gomes, R.D.; Fonseca, I.E.; Benavente-Peces, C. Survey and systematic mapping of industrial Wireless Sensor Networks. J. Netw. Comput. Appl. 2017, 97, 96-125. [CrossRef]

97. Bayou, L.; Espes, D.; Cuppens-Boulahia, N.; Cuppens, F. Security analysis of WirelessHART communication scheme. In International Symposium on Foundations and Practice of Security; Springer: Berlin/Heidelberg, Germany, 2016; pp. 223-238.

98. Gavrić, Ž.; Simić, D. Overview of DOS attacks on wireless sensor networks and experimental results for simulation of interference attacks. Ing. Investig. 2018, 38, 130-138. [CrossRef]

99. Nikolidakis, S.A.; Kandris, D.; Vergados, D.D.; Douligeris, C. Energy efficient routing in wireless sensor networks through balanced clustering. Algorithms 2013, 6, 29-42. [CrossRef]

100. Habib, G.; Haddad, N.; El Khoury, R. Case study: WIRELESSHART vs ZIGBEE network. In Proceedings of the 2015 Third International Conference on Technological Advances in Electrical, Electronics and Computer Engineering (TAEECE), Beirut, Lebanon, 29 April-1 May 2015; pp. 135-138.

101. Karakaya, A.; Akleylek, S. A survey on security threats and authentication approaches in wireless sensor networks. In Proceedings of the 2018 6th International Symposium on Digital Forensic and Security (ISDFS), Antalya, Turkey, 22-25 March 2018; pp. 1-4. 
102. Zhang, Q.; Li, F.; Ju, L.; Jia, Z.; Zhang, Z. Reliable and energy efficient routing algorithm for WirelessHART. In International Conference on Algorithms and Architectures for Parallel Processing; Springer: Berlin/Heidelberg, Germany, 2014; pp. 192-203.

103. Ramos, B.; Savazzi, S.; Winter, J.; Ojeda, V.; Chalen, M.; Del Rosario, E.; others. A Perfomance Comparison of WirelessHART and ZigBee in Oil Refinery. In Proceedings of the 2018 IEEE-APS Topical Conference on Antennas and Propagation in Wireless Communications (APWC), Cartagena, Colombia, 10-14 September 2018; pp. 846-849.

104. Ma, J.; Yang, D.; Zhang, H.; Gidlund, M. A reliable handoff mechanism for mobile industrial wireless sensor networks. Sensors 2017, 17, 1797. [CrossRef] [PubMed]

105. Wu, C.; Gunatilaka, D.; Saifullah, A.; Sha, M.; Tiwari, P.B.; Lu, C.; Chen, Y. Maximizing network lifetime of WirelessHART networks under graph routing. In Proceedings of the 2016 IEEE First International Conference on Internet-of-Things Design and Implementation (IoTDI), Berlin, Germany, 4-8 April 2016; pp. 176-186.

106. Nobre, M.; Silva, I.; Guedes, L.A. Performance evaluation of WirelessHART networks using a new network simulator 3 module. Comput. Electr. Eng. 2015, 41, 325-341. [CrossRef]

107. Xiao, X.; Huang, H.; Wang, W. Underwater Wireless Sensor Networks: An Energy-Efficient Clustering Routing Protocol Based on Data Fusion and Genetic Algorithms. Appl. Sci. 2021, 11, 312.

108. Devan, P.A.M.; Hussin, F.A.; Ibrahim, R.; Bingi, K.; Abdulrab, H. Fractional-order Predictive PI Controller for Process Plants with Deadtime. In Proceedings of the 2020 IEEE 8th R10 Humanitarian Technology Conference (R10-HTC), Kuching, Malaysia, 1-3 December 2020; pp. 1-6.

109. Raza, S.; Faheem, M.; Guenes, M. Industrial wireless sensor and actuator networks in industry 4.0: Exploring requirements, protocols, and challenges-A MAC survey. Int. J. Commun. Syst. 2019, 32, e4074. [CrossRef]

110. Wu, Y.; Zhang, W.; He, H.; Liu, Y. A New Method of Priority Assignment for Real-Time Flows in the WirelessHART Network by the TDMA Protocol. Sensors 2018, 18, 4242. [CrossRef]

111. Givehchi, O.; Landsdorf, K.; Simoens, P.; Colombo, A.W. Interoperability for industrial cyber-physical systems: An approach for legacy systems. IEEE Trans. Ind. Inform. 2017, 13, 3370-3378. [CrossRef]

112. Oyewobi, S.S.; Hancke, G.P. A survey of cognitive radio handoff schemes, challenges and issues for industrial wireless sensor networks (CR-IWSN). J. Netw. Comput. Appl. 2017, 97, 140-156. [CrossRef]

113. Karray, F.; Jmal, M.W.; Garcia-Ortiz, A.; Abid, M.; Obeid, A.M. A comprehensive survey on wireless sensor node hardware platforms. Comput. Networks 2018, 144, 89-110. [CrossRef]

114. Bergmann, N.W.; Hou, L. Machine condition monitoring with industrial wireless sensor networks. In Industrial Wireless Sensor Networks; CRC Press: Boca Raton, FL, USA, 2017, pp. 23-45. doi:10.1201/b14072. [CrossRef]

115. Kharb, S.; Singhrova, A. Review of industrial standards for wireless sensor networks. In Next-Generation Networks; Springer: Berlin/Heidelberg, Germany, 2018; pp. 77-87.

116. He, X.; Fu, X.; Yang, Y. Energy-efficient trajectory planning algorithm based on multi-objective PSO for the mobile sink in wireless sensor networks. IEEE Access 2019, 7, 176204-176217. [CrossRef]

117. Goyal, N.; Dave, M.; Verma, A.K. Improved data aggregation for cluster based underwater wireless sensor networks. Proc. Natl. Acad. Sci. India Sect. A Phys. Sci. 2017, 87, 235-245. [CrossRef]

118. Nakas, C.; Kandris, D.; Visvardis, G. Energy efficient routing in wireless sensor networks: A comprehensive survey. Algorithms 2020, 13, 72. [CrossRef]

119. Xiao, G.; Shi, J.; Sun, N.; Chen, Y.; Zhang, Y. Adaptive Freeshape Clustering for Balanced Energy Saving in the WirelessHART Networks. Complexity 2019, 2019, 2836981. [CrossRef]

120. Ibrahim, R.; Chung, T.D.; Hassan, S.M.; Bingi, K.; binti Salahuddin, S.K. Solar energy harvester for industrial wireless sensor nodes. Procedia Comput. Sci. 2017, 105, 111-118. [CrossRef]

121. Shaikh, F.K.; Zeadally, S. Energy harvesting in wireless sensor networks: A comprehensive review. Renew. Sustain. Energy Rev. 2016, 55, 1041-1054. [CrossRef]

122. Sha, K.; Gehlot, J.; Greve, R. Multipath routing techniques in wireless sensor networks: A survey. Wirel. Pers. Commun. 2013, 70, 807-829. [CrossRef]

123. Fanian, F.; Rafsanjani, M.K. Cluster-based routing protocols in wireless sensor networks: A survey based on methodology. J. Netw. Comput. Appl. 2019, 142, 111-142. [CrossRef]

124. Patel, H.; Singh Rajput, D.; Thippa Reddy, G.; Iwendi, C.; Kashif Bashir, A.; Jo, O. A review on classification of imbalanced data for wireless sensor networks. Int. J. Distrib. Sens. Netw. 2020, 16, 1550147720916404. [CrossRef]

125. Boubiche, S.; Boubiche, D.E.; Bilami, A.; Toral-Cruz, H. Big data challenges and data aggregation strategies in wireless sensor networks. IEEE Access 2018, 6, 20558-20571. [CrossRef]

126. Randhawa, S.; Jain, S. Data aggregation in wireless sensor networks: Previous research, current status and future directions. Wirel. Pers. Commun. 2017, 97, 3355-3425. [CrossRef]

127. Chouikhi, S.; El Korbi, I.; Ghamri-Doudane, Y.; Saidane, L.A. A survey on fault tolerance in small and large scale wireless sensor networks. Comput. Commun. 2015, 69, 22-37. [CrossRef]

128. Geng, Z.; Dong, J.; Chen, J.; Han, Y. A new self-organizing extreme learning machine soft sensor model and its applications in complicated chemical processes. Eng. Appl. Artif. Intell. 2017, 62, 38-50. [CrossRef] 
129. Kamimura, A.; Tomita, K. A self-organizing network coordination framework enabling collision-free and congestion-less wireless sensor networks. J. Netw. Comput. Appl. 2017, 93, 228-244. [CrossRef]

130. Kostadinovic, M.; Stjepanovic, A.; Kuzmic, G.; Stojcic, M.; Kostadinovic, T. Quality Analysis of Data Transferring Through the Process of Modeling WirelessHART Network. In Proceedings of the 2020 19th International Symposium INFOTEH-JAHORINA (INFOTEH), East Sarajevo, Bosnia and Herzegovina, 18-20 March 2020; pp. 1-5.

131. Li, F.; Zhang, Z.; Jia, Z.; Ju, L. Superframe scheduling for data aggregation in WirelessHART networks. In Proceedings of the 2015 IEEE 17th International Conference on High Performance Computing and Communications, 2015 IEEE 7th International Symposium on Cyberspace Safety and Security, and 2015 IEEE 12th International Conference on Embedded Software and Systems, New York, NY, USA, 24-26 August 2015; pp. 1540-1545.

132. Jindal, V.; Verma, A. The underlying technologies in WSNs: ZigBee vs. wireless HART. In Proceedings of the 201512 th International Conference on Fuzzy Systems and Knowledge Discovery (FSKD), Zhangiajie, China, 15-17 August 2015; pp. $2208-2213$.

133. Künzel, G.; Cainelli, G.P.; Pereira, C.E. A weighted broadcast routing algorithm for wirelesshart networks. In Proceedings of the 2017 VII Brazilian Symposium on Computing Systems Engineering (SBESC), Curitiba, PR, Brazil, 6-10 November 2017; pp. 187-192.

134. Supramaniam, T.; Ibrahim, R.; Hassan, S.M.; Bingi, K. Development of WirelessHART adapter with industrial transmitter for process monitoring. In Proceedings of the 2017 IEEE International Conference on Signal and Image Processing Applications (ICSIPA), Kuching, Malaysia, 12-14 September 2017; pp. 294-298.

135. Chen, G.; Cao, X.; Jin, J. Joint Scheduling and Channel Allocation for Kalman Filtering over Multihop WirelessHART Networks. IEEE Trans. Ind. Inform. 2020, 17, pp. 3555-3565.

. [CrossRef]

136. Benoit, J.; Yao, A.; Saladis, L.; Zheng, Y. Performance evaluations of multi-hop wirelessHART network and 6LoWPAN using different topologies. In Proceedings of the 2018 Global Smart Industry Conference (GloSIC), Chelyabinsk, Russia, 13-15 November 2018; pp. 1-5.

137. Modekurthy, V.P.; Saifullah, A.; Madria, S. Distributed graph routing for wirelesshart networks. In Proceedings of the 19th International Conference on Distributed Computing and Networking (ICDCN '18) Varanasi, India, 4 -7 January 2018; pp. 1-10.

138. Saifullah, A.; Gunatilaka, D.; Tiwari, P.; Sha, M.; Lu, C.; Li, B.; Wu, C.; Chen, Y. Schedulability analysis under graph routing in WirelessHART networks. In Proceedings of the 2015 IEEE Real-Time Systems Symposium, San Antonio, TX, USA, 1-4 December 2015; pp. $165-174$.

139. Li, F.; Ju, L.; Jia, Z. Data aggregation framework for energy-efficient WirelessHART networks. J. Syst. Archit. 2016, 63, 70-79. [CrossRef]

140. Ji, M.; Cao, X. Joint Design of Routing and Scheduling for Maximizing Reliability of Multihop Transmissions in WirelessHART Networks. In Proceedings of the 2020 35th Youth Academic Annual Conference of Chinese Association of Automation (YAC), Zhanjiang, China, 16-18 October 2020; pp. 269-275.

141. Paul, P.; Ram, N.; Usha, M. Symmetric key encryption for secure communication using wireless hart in wireless sensor networks (WSN). Aust. J. Basic Appl. Sci. 2016, 10, 625-630.

142. Mota, A.V.; Azam, S.; Shanmugam, B.; Yeo, K.C.; Kannoorpatti, K. Comparative analysis of different techniques of encryption for secured data transmission. In Proceedings of the 2017 IEEE International Conference on Power, Control, Signals and Instrumentation Engineering (ICPCSI), Chennai, Tamil Nadu, India, 21-22 September 2017; pp. 231-237.

143. Bayou, L.; Espes, D.; Cuppens-Boulahia, N.; Cuppens, F. Security issue of wirelesshart based SCADA systems. In International Conference on Risks and Security of Internet and Systems; Springer: Berlin/Heidelberg, Germany, 2015, pp. $225-241$.

144. Adriano, J.D.; do Rosario, E.C.; Rodrigues, J.J. Wireless sensor networks in industry 4.0: WirelessHART and ISA100. 11a. In Proceedings of the 2018 13th IEEE International Conference on Industry Applications (INDUSCON), Sao Paulo, Brazil, 12-14 November 2018; pp. 924-929.

145. Noura, M.; Atiquzzaman, M.; Gaedke, M. Interoperability in internet of things: Taxonomies and open challenges. Mob. Netw. Appl. 2019, 24, 796-809. [CrossRef] 